\title{
X-ray fluorescence core scanning, magnetic signatures, and organic geochemistry analyses of Ryukyu Trench sediments: turbidites and hemipelagites
}

Kan-Hsi Hsiung ${ }^{1 *}$ D, Toshiya Kanamatsu ${ }^{1}$, Ken Ikehara ${ }^{2}$, Kazuko Usami ${ }^{3}$, Chorng-Shern Horng ${ }^{4}$, Naohiko Ohkouchi ${ }^{1}$, Nanako O. Ogawa', Saneatsu Saito ${ }^{1}$ and Masafumi Murayama ${ }^{5}$

\begin{abstract}
The southwestern Ryukyu Trench represents the ultimate sink of sediments shed from Taiwan into the Philippine Sea, which are mainly transported to the trench by turbidity currents via submarine canyons. Here, we present trench turbidites intercalated with hemipelagites in a gravity pilot core and a piston core acquired on the Ryukyu Trench floor at $6147 \mathrm{~m}$ water depth. We performed X-ray fluorescence core scans (ITRAX profiles), magnetic measurements, and organic geochemistry analyses to discriminate turbidites from hemipelagites. We identified 36 turbidites (0.9-4.2 cm thick) based on visual core descriptions and $\mathrm{Ca} / \mathrm{Fe}$ ratios in the ITRAX profiles. Three of these turbidites show magnetic signatures indicating the presence of pyrrhotite and peaks in the magnetic susceptibility profile, suggesting that Taiwan-sourced sediments are transported to the Ryukyu Trench by long-runout turbidity currents. Pyrrhotite is also present in hemipelagites of the upper part of the retrieved cores, indicating a dominant sediment source in Taiwan over the last several thousand years. $\mathrm{Ca} / \mathrm{Fe}$ and $\mathrm{Zr} / \mathrm{Rb}$ ratios in the ITRAX profiles mark distal turbidites (about 1-3 cm thick), and $\mathrm{Zr} / \mathrm{Rb}$ peaks mainly reflect grain size changes. Detailed analyses of a representative turbidite show good correlation between $\mathrm{Ca} / \mathrm{Fe}$ and $\mathrm{Zr} / \mathrm{Rb}$ peaks with upward-coarsening and upwardfining trends that delimit the turbidite. Sedimentary organic matter in hemipelagites is characterized by higher total organic carbon and total nitrogen contents and higher $\delta^{13} \mathrm{C}$ values than that in turbidites. Our multi-proxy approach employing high-resolution XRF core scans to differentiate turbidites from hemipelagites contributes to establishing a comprehensive view of modern trench sedimentation from Taiwan to the southwestern Ryukyu Trench.
\end{abstract}

Keywords: Distal turbidites, ITRAX, Pyrrhotite, Ryukyu Trench, Taiwan

\section{Introduction}

Oceanic trenches are the most significant elongate depressions on the seafloor along subduction zones and are generally thousands of kilometers long, up to $8 \mathrm{~km}$ deep, and tens to hundreds of kilometers wide (Jarrard 1986; Stern 2002). In the source-to-sink scheme (e.g., Sømme et al. 2009; Covault et al. 2011), trenches

\footnotetext{
* Correspondence: hsiung@jamstec.go.jp

${ }^{1}$ Yokosuka Headquarters, Japan Agency for Marine-Earth Science and

Technology, 2-15, Natsushima-cho, Yokosuka-city, Kanagawa 237-0061, Japan Full list of author information is available at the end of the article
}

represent the ultimate sinks of regional sediment transport along convergent margins. There are two fundamental transport routes for sediment filling the trench floor: generally, trench-filling sediments are transported downslope from adjacent forearc ridges by gravity-driven sediment flows, whereas axial sediment transport plays an important role in delivering terrigenous sediments to the trench floor (e.g., Hsiung et al. 2015; Malatesta et al. 2013). Some large deepsea channels along trench axes, such as the middle Chile Trench and the Nankai and Zenisu Troughs (Thornburg and Kulm 1987; Le Pichon et al. 1987; Wu et al. 2005), also 
indicate active sediment transport on the trench floors. Sediments accumulated within the trench tend to form a wedgeshaped package of deposits (i.e., the trench wedge) that increases in thickness toward the accretionary prism (Davis et al. 1983). Trench-fill deposits are commonly characterized by fine-grained turbidites, which result from turbidity currents within submarine canyons and channels of the trench (Stow and Shanmugam 1980). The Japan Trench, however, lacks a major canyon system; there, turbidity currents are triggered by large earthquakes and related tsunamis (Ikehara et al. 2016, 2018). However, reported ages of turbidites and hemipelagic muds in core samples from the landward slope of the Japan Trench are variable (Usami et al. 2018; Ikehara et al. 2020). Advanced understanding of discrepancies of sedimentation rates from distinct trenches are important to improve the knowledge of trench sedimentation.

The southwestern Ryukyu Trench near Taiwan (Fig. 1) is an ideal location for studying trench deposits within a source-to-sink framework because of the distinct sediment transport routes from their terrestrial source in Taiwan to their ultimate sink in the trench. Hsiung et al. (2017) suggested that deposits in the western end of the Ryukyu Trench record the accumulation of sediments derived from the distal source in Taiwan, transported mainly by turbidity currents down the Hualien and Taitung Canyons. To date, those trench turbidite deposits have mainly been interpreted on the basis of seismic facies characteristics and major sedimentary features, but these interpretations lack constraints from core samples (Hsiung et al. 2017). The main objective of this study is therefore to verify the provenance of Ryukyu Trench sediments based on analyses of core samples acquired by the Japan Agency for Marine-Earth Science and Technology (JAMSTEC) in 2015. These newly acquired cores were characterized by integrating X-ray fluorescence (XRF) core scanning, magnetic measurements, and organic geochemistry. We use our analyses to understand the origins of turbidites (particularly distal turbidites) in Ryukyu Trench deposits, which contain crucial information on far-field sediment transport. Our results contribute to establishing a comprehensive view of modern trench sedimentation by documenting the efficient sediment transport from Taiwan to the southwestern Ryukyu Trench. Besides, radiocarbon dating provides age model constraints for the Ryukyu Trench floor.

\subsection{Regional setting of the southwestern Ryukyu Trench}

The oceanic crust of the northern Huatung Basin and west of the Gagua Ridge is actively subducting northward beneath the Ryukyu Trench (Schnürle et al. 1998). The southwestern Ryukyu Trench is indented by the northern part of the Gagua Ridge and is characterized by a curved, fan-shaped trench floor (Fig. 1). Bathymetry and seismic reflection profiles show the tilting trench wedge in the western end of the Ryukyu Trench (Fig. 2), implying sediment deposition rather than erosion in this area. The connection between the Hualien Canyon, east of Taiwan, and the Ryukyu Trench is a major seaward transport route for orogenic sediments shed from the island of Taiwan (Hsiung et al. 2017). The sediment flux delivered to the ocean from eastern Taiwanese rivers has been estimated to be about $44 \mathrm{Mt} /$ year (Dadson et al. 2005) to $79.4 \pm$ 13.8 Mt/year (Kao and Milliman 2008). Large volumes of orogenic sediment eroded from the Taiwan orogenic belt are transported seaward and deposited as a $\sim 4 \mathrm{~km}$-thick sequence in the confined Huatung Basin. The major sediment transport routes from Taiwan to the southwestern Ryukyu Trench floor have been determined from bathymetric and seismic reflection data (Hsiung et al. 2017). The different water depths in the Huatung Basin $(\sim 4000$ $\mathrm{m})$ and the West Philippine Sea Basin ( 6300 m) imply that the Gagua Ridge is a natural boundary preventing the transport of sediments farther eastward (Van Avendonk et al. 2014; Lehu et al. 2015).

North of the Ryukyu Trench, the Ryukyu Island Arc was formed as a consequence of the subduction of the Philippine Sea Plate beneath the Eurasia Plate (Karig 1973; Angelier 1986). The Ryukyu subduction system extends $2200 \mathrm{~km}$ southwest from Kyushu Island, Japan, to northern Taiwan and includes the Ryukyu Trench, the Yaeyama accretionary prism, several forearc basins, the Ryukyu Islands, and several backarc basins (Dominguez et al. 1998; Schnürle et al. 1998). The forearc basins are semi-isolated intra-slope basins that parallel the southwestern Ryukyu Trench. The Yaeyama Ridge, the frontal part of the accretionary prism created by subduction in the southwest Ryukyu Trench, forms a linear boundary separating the accretionary prism from the forearc basins. The Ryukyu Trench wedge is mainly fed from two directions: (1) Taiwan-sourced sediments from the west and (2) sediments eroded from the Yaeyama Ridge and Ryukyu island arc to the north (Hsiung et al. 2017). The southwestern Ryukyu Trench floor can be regarded as the ultimate sink for sediments derived from the Yaeyama Ridge and is isolated from the Ryukyu forearc basins. Because there are no obvious submarine canyons or channels providing sediment pathways across the Yaeyama Ridge and forearc basins, the sediment flux to the Ryukyu Trench floor from the Ryukyu Islands and Yaeyama Ridge is expected to be small compared to that from Taiwan. The southwestern Ryukyu Trench wedge is about $0.8-1.0 \mathrm{~km}$ thick ( $1 \mathrm{~s}$ two-way travel time), as estimated from seismic reflection profiles (Fig. 2b). The braided channel along the trench axis indicates sediment transport by axial flows (Fig. 2a). Specifically, the southwestern Ryukyu Trench has received a large amount of sediment from Taiwan since its uplift began about 8.06.5 Ma (Lin et al. 2003; Sibuet and Hsu 2004). The 


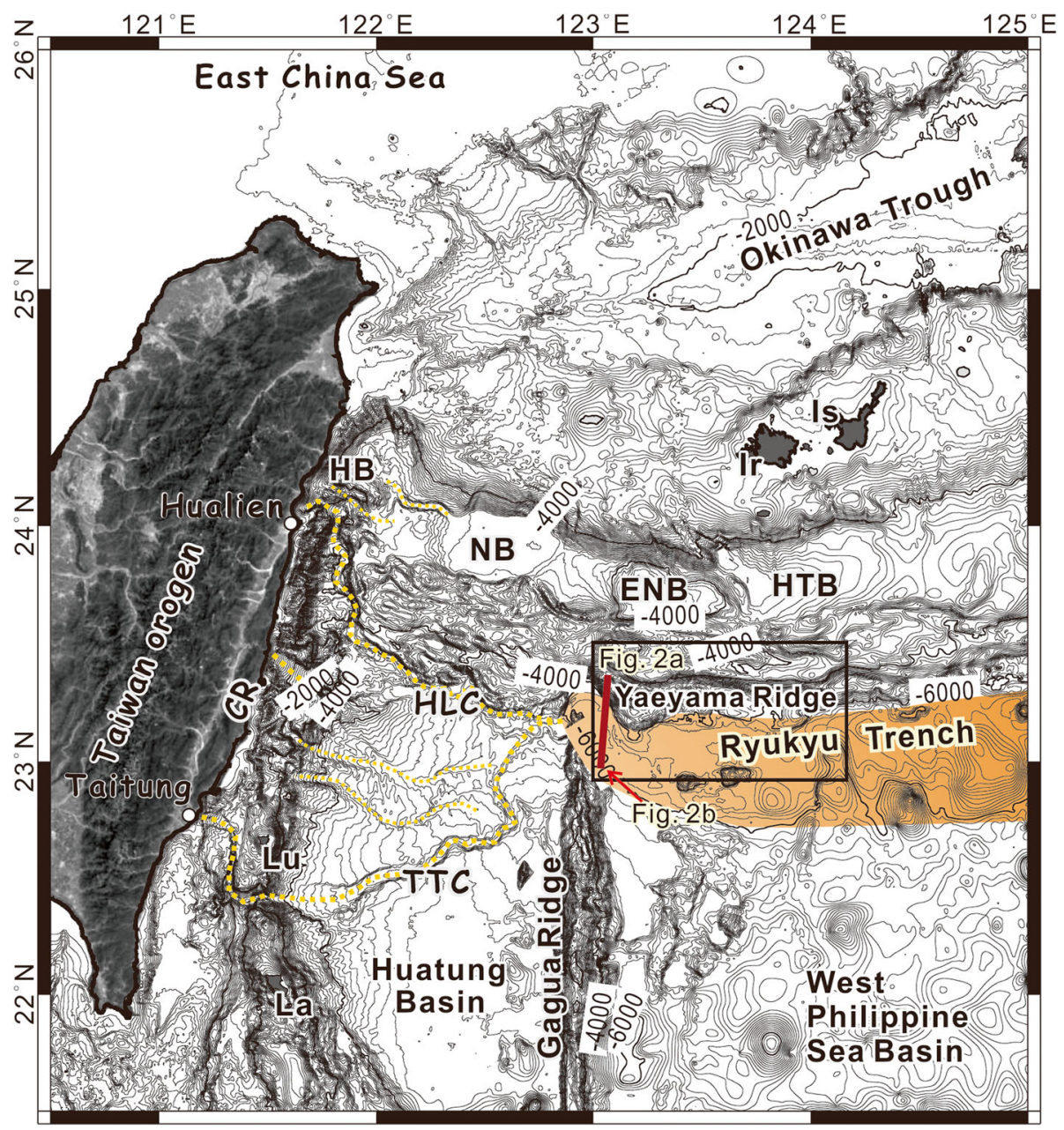

Fig. 1 Regional bathymetric map of the southwestern Ryukyu subduction zone between Taiwan and Iriomote Island. The southwestern Ryukyu Trench (shaded orange) terminates at Gagua Ridge, which separates the Huatung and West Philippine Sea basins. Several large canyons (yellow broken lines) incise the narrow slope off eastern Taiwan and extend into the Huatung Basin. CR, coastal range; HB, Hoping Basin; NB, Nanao Basin; ENB, East Nanao Basin; HTB, Hateruma Basin; Ir, Iriomote Island; Is, Ishigaki Island; HLC, Hualien Canyon; TTC, Taitung Canyon; and Lu and La, Lutao-Lanyu Ridge (i.e., the Luzon arc). The square indicates the area shown in Fig. 2a, and the red solid line the location of seismic reflection profile line 89 (Fig. 2b)

geophysical aspects of the southwestern Ryukyu subduction zone, particularly its perpendicular link with the Taiwan collision zone, have been intensively studied (e.g., Lallemand et al. 1997, 2013). In contrast, sedimentation along the southwestern Ryukyu Trench floor has not been well studied. The southwestern Ryukyu Trench is thus a suitable study area for examining distal turbidite transport and emplacement along subduction zones.

\section{Samples and methods}

\subsection{Bathymetry, piston core, and radiography}

Swath bathymetric data used in this study were collected in 2015 during JAMSTEC cruises YK15-01 by R/V Yokosuka and KR15-18 by R/V Kairei (JAMSTEC 2015, 2016). To better determine the course of the braided axial channel, the high-resolution bathymetric map was redrawn using GeomapApp (Fig. 2a). Cores were drilled at $6147 \mathrm{~m}$ water depth at $23^{\circ} 02^{\prime} 31^{\prime \prime} \mathrm{N}, 123^{\circ} 07^{\prime} 42^{\prime \prime} \mathrm{E}$, behind the channel levee on the trench floor near the end of the trench, during cruise KR15-18 (Fig. 2a). An 8 m-long piston coring system with $7.8 \mathrm{~cm}$-diameter core liners was used to collect piston core PC04 (length $532 \mathrm{~cm}$ ) and gravity pilot core PL04 (length $76.5 \mathrm{~cm}$ ). Based on the corer setup, the bottom of PL04 corresponds to $<20 \mathrm{~cm}$ above the top of PC04. Both cores were split laterally onboard and physically described. X-radiographs were taken of slab samples of PC04 $(1 \mathrm{~cm}$ thick and $20 \mathrm{~cm}$ long $)$ to observe detailed sedimentary structures (Fig. 3).

\subsection{XRF core scanning analysis}

The elemental compositions of the cores were logged using an ITRAX XRF Core Scanner (ITRAX hereafter) 

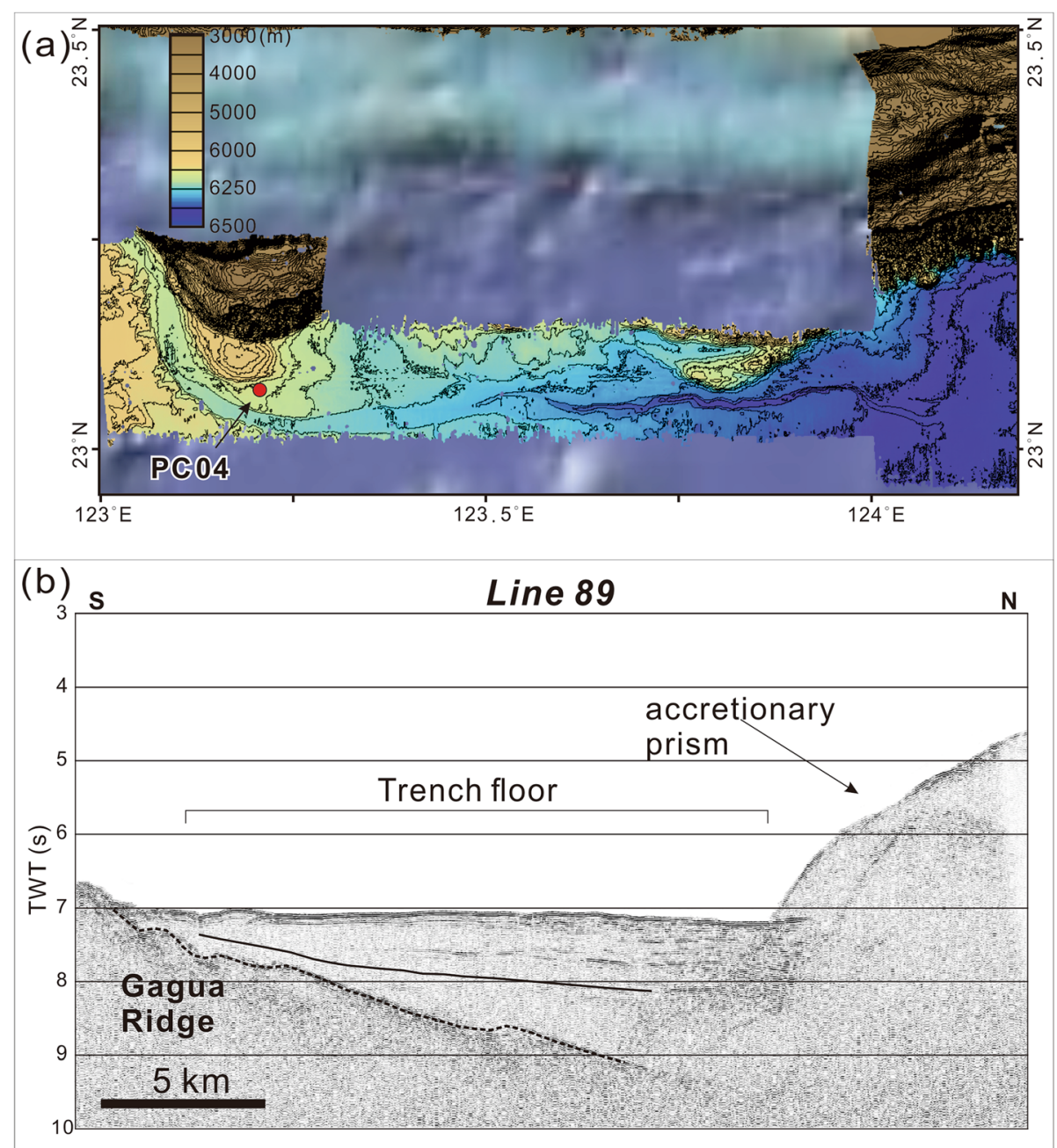

Fig. 2 a Detailed bathymetry of the southwestern Ryukyu Trench. Cores PL04 and PCO4 (red circle) were drilled in the north levee of the axial channel of the Ryukyu Trench floor. b Seismic reflection profile line 89 runs roughly N-S through the study area (red solid line in Fig. 1). Depth is represented as two-way travel time (TWT)

at Kochi Core Center, Japan. The ITRAX X-ray beam $(0.2 \times 20 \mathrm{~mm})$ is used to irradiate (excite) samples to generate radiographic images and energy dispersive XRF spectra (Croudace et al. 2006; Löwemark et al. 2019). The ITRAX data are normally output as counts and can be considered semiquantitative relative to elemental intensities. PC04 was scanned at a resolution of $0.10 \mathrm{~cm}$, and the reported elemental ratios were calculated as five-point running averages; PL04 was scanned at $0.05 \mathrm{~cm}$ resolution, and the reported elemental ratios were calculated as ten-point running averages (Fig. 3).

\subsection{Magnetic parameters}

Samples for magnetic analyses were packed in $7 \mathrm{~cm}^{3}$ plastic cubes at $2.2 \mathrm{~cm}$ intervals spanning the entire cores and analyzed using a KLY-4 magnetic susceptibility meter (AGICO Inc.). A total of 145 cubes from
PC04 and 33 cubes from PL04 were measured at JAMSTEC Yokosuka headquarters, Japan. Magnetic hysteresis loops and direct-current demagnetizations were measured by a vibrating sample magnetometer (VSM) at the Institute of Earth Sciences, Academia Sinica, Taiwan, and the JAMSTEC Yokosuka headquarters, respectively. A total of 38 dry bulk samples from separate layers at different core depths were selected and stored in capsules (ca. $0.2 \mathrm{~g}$ each) from PL04 and PC04. Hysteresis loops were measured on each capsule at an applied field of $0.5 \mathrm{~T}$. Hysteresis parameters including the saturation remanent magnetization $(\mathrm{Mr})$, saturation magnetization (Ms), coercivity ( $\mathrm{Hc})$, and coercivity of remanence $(\mathrm{Hcr})$ were calculated. Magnetic parameters, including magnetic susceptibility (MS), the minimum principal axis of the anisotropy of magnetic inclination (K3), Hc, Hcr, Mr, and Ms, are plotted against core depth (Fig. 4). 


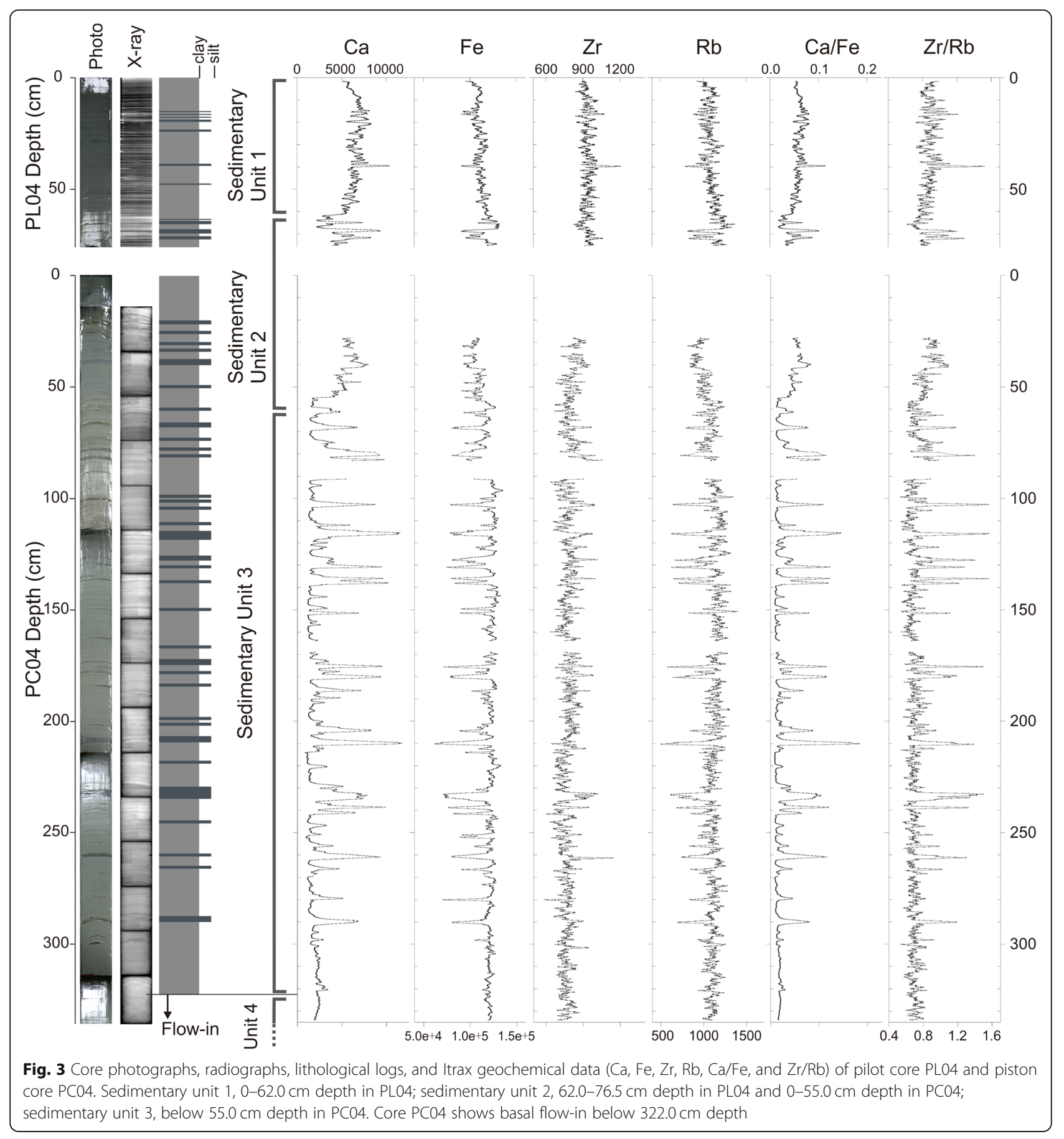

A total of 30 discrete samples (ca. $0.2 \mathrm{~g}$ each) were dried and stored in capsules and analyzed with a quantum design superconducting quantum interference vibrating sample magnetometer (SQUID-VSM) at the Institute of Earth Sciences, Academia Sinica. SQUIDVSM analyses provide rapid identification of pyrrhotite in bulk samples on the basis of its low-temperature magnetic transition at $34 \mathrm{~K}$. To detect low-temperature magnetic transitions in the core samples, their remanent magnetizations were measured during cooling from 300 to $5 \mathrm{~K}$ in a zero field in the SQUID-VSM. At $5 \mathrm{~K}$, a 5 T DC field was momentarily applied to impart a saturation isothermal remanent magnetization (Hsiung et al. 2017). The SQUID-VSM patterns and the Day plot (Day et al. 1977) of hysteresis parameters are presented in Fig. 5. The presence/absence of pyrrhotite with depth in the core is marked by closed/open diamonds in Fig. 4. 


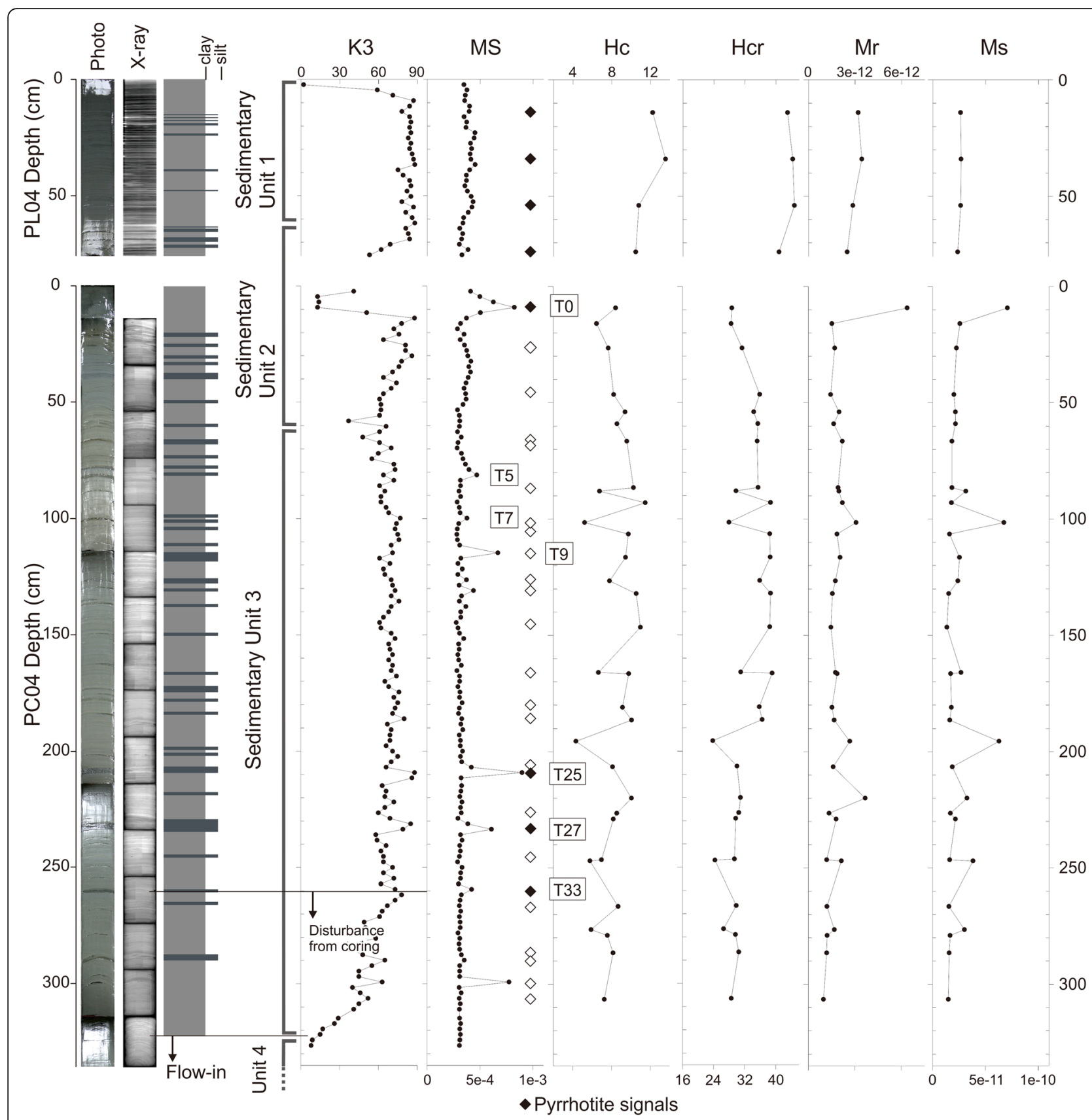

Fig. 4 Magnetic hysteresis parameters ( $\mathrm{Hc}, \mathrm{Hcr}, \mathrm{Mr}$, and Ms) from vibrating sample magnetometry (VSM), and magnetic susceptibility (MS) and K3 inclination (K3) measured using a KLY-4 magnetic susceptibility meter. Solid diamonds in the MS column indicate the presence of both pyrrhotite (transition at $34 \mathrm{~K}$ ) and magnetite (119 K) as determined from SQUID-VSM (see Fig. 5a, b); open diamonds indicate magnetite only (see Fig. 5c, d). Peaks in the MS profile that correlate with identified turbidites are labeled. Increasing disturbance of PC04 by coring is noticeable below $262 \mathrm{~cm}$ depth

2.4 Sediment particle observations and grain size analysis Regarding the preservation of the core surface, we chose turbidite $\mathrm{T} 25$ as a representative of the pyrrhotitebearing turbidites (i.e., T25, T27, and T33). To determine grain size variations in coarse-grained layers, we selected turbidite T25 (a $\sim 3 \mathrm{~cm}$-thick silty sand layer) and $\sim 1 \mathrm{~cm}$-thick sections of clay sediments directly above and below it for grain size analyses by a Morphologi-G3 particle characterization system (M-G3) at JAMSTEC Yokosuka Headquarters, Japan.

The sample set included 10 specimens (at $0.5 \mathrm{~cm}$ intervals, $\sim 13 \mathrm{~mm}^{3}$ each) from 207.0 to $212.0 \mathrm{~cm}$ depth in PC04, which were prepared and dried in a freeze-dryer for dispersion analyses. We used the software of the M-G3 to 

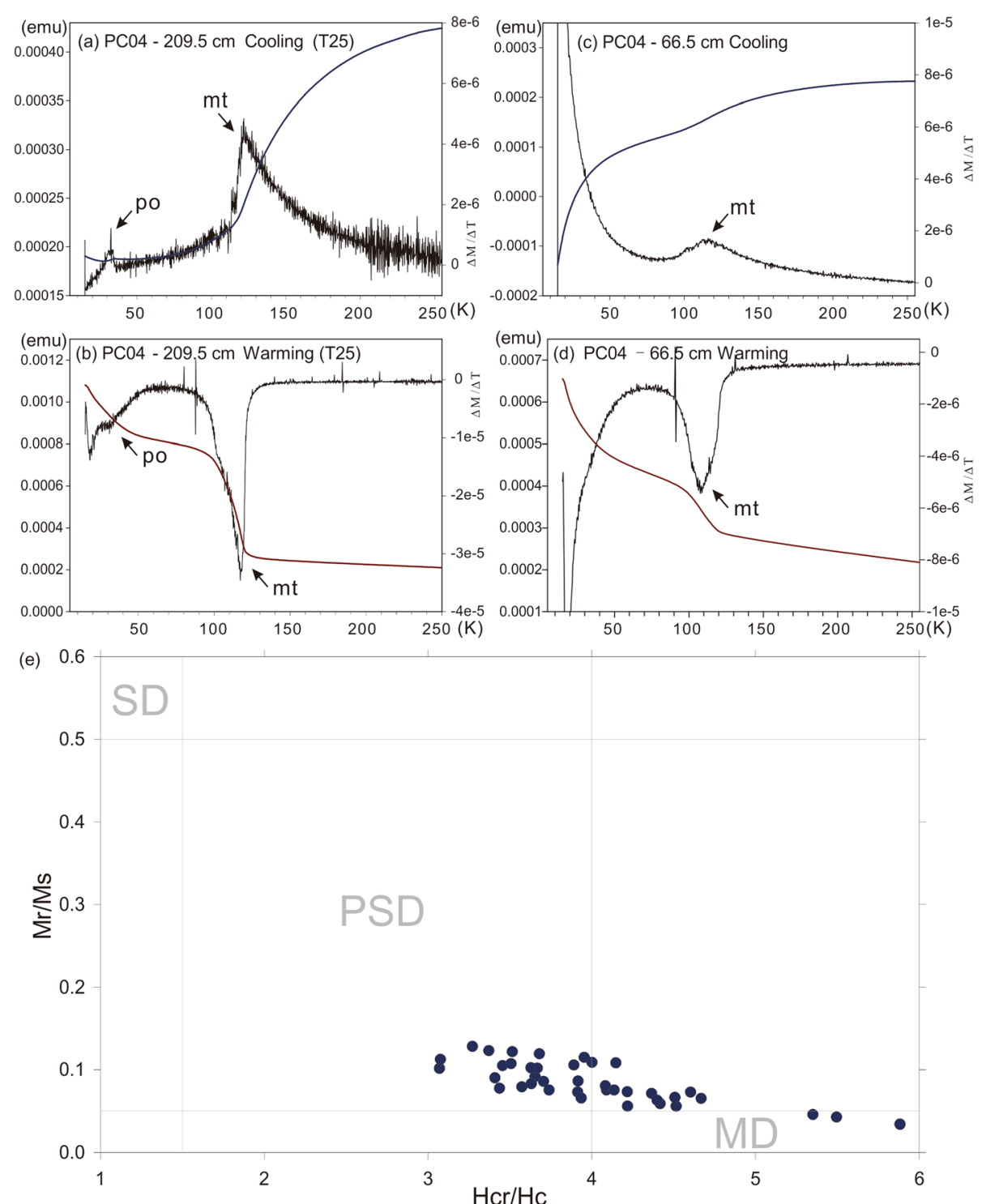

Fig. 5 SQUID-VSM magnetic susceptibility analyses of bulk marine sediments from $\mathbf{a}$, b 209.5 and $\mathbf{c}$, d $66.5 \mathrm{~cm}$ depth in PC04 during a, c cooling and $\mathbf{b}$, d warming over temperatures from $5 \mathrm{~K}$ to room temperature. Both heating and cooling rates were $3 \mathrm{~K} / \mathrm{min}$. The magnetic susceptibility scale (emu) on the left of each plot is reported as $\Delta M / \Delta T$ on the right. Peaks at $119 \mathrm{~K}$ and $34 \mathrm{~K}$ indicate the presence of magnetite (mt) and pyrrhotite (po), respectively, in the bulk sediments. Pyrrhotite peaks are observed throughout PL04 and in three turbidite beds in PC04. e Day plot (Day et al. 1977) of hysteresis magnetization and coercivity parameter ratios. The clastic mud beds and silty-sand laminae samples plot in the pseudo-single domain (PSD) and multi-domain (MD) fields, indicating that most of the magnetic particles are uniformly fine-grained

count particles and scan particle images. The M-G3 was operated in its automatic standard mode (Malvern Instruments Ltd. 2017; Becker et al. 2018). The M-G3 can detect dry particles with circle-equivalent diameters (CE) of 0.54-1000 $\mu \mathrm{m}$ (Malvern Instruments Ltd. 2017). Because most of the sediments are fine particles, the $\times 20$ lens was selected for particle morphological analyses. We analyzed more than 200,000 particles from each sample to achieve statistically representative populations. After particle analyses, we calculated statistical parameters including aspect ratio (the ratio of width to height) and circularity (the circumference of a circle of equivalent area divided by the actual perimeter). The grain size scale and classification scheme are based on Blott and Pye (2012).

\subsection{Radiocarbon dating and organic geochemistry}

Eight horizons were selected from PC04 to determine radiocarbon ages from the dried bulk sediments. Radiocarbon dating was performed by accelerator mass spectrometry at Beta Analytic Co., Ltd. Each dried sample $(\sim 10 \mathrm{mg})$ of finely powdered sediment was washed with $1 \mathrm{~N} \mathrm{HCl}$ at $80^{\circ} \mathrm{C}$ to remove carbonates. Eighteen further 
horizons were selected from specific mud and silty sand beds to analyze total organic carbon (TOC, wt.\%), total nitrogen (TN, wt.\%), and the stable carbon isotopic composition of TOC $\left(\delta^{13} \mathrm{C}\right.$, \% vs VPDB). Determinations of TOC, TN, and $\delta^{13} \mathrm{C}$ were performed using a highsensitivity elemental analyzer-isotope ratio mass spectrometer (EA-IRMS) comprising a modified elemental analyzer (Flash EA1112), a continuous flow interface (ConFloIII), and an isotope ratio mass spectrometer (Delta plus XP IRMS; all from Thermo Finnigan, Bremen, Germany) as described in Ogawa et al. (2010). Each sediment sample was treated with $0.1 \mathrm{M}$ $\mathrm{HCl}$ prior to EA-IRMS analysis to remove carbonates. $\mathrm{C}$ and $\mathrm{N}$ abundances and $\mathrm{C}$ isotopic compositions were calibrated against the interlaboratory reference material L-tyrosine (BG-T; $N=7.7 \mathrm{wt} . \%, \mathrm{C}$ $=59.7 \mathrm{wt} . \%, \delta^{13} \mathrm{C}=-20.83 \pm 0.13 \%$ ) , the $\delta^{13} \mathrm{C}$ value of which was determined based on multiple international standards (Tayasu et al. 2011). The quantitative and analytical errors on TOC, TN, and $\delta^{13} \mathrm{C}$ were $\pm 0.25 \mu \mathrm{g} \mathrm{C}(1.4-9.6 \mu \mathrm{g} \mathrm{C}), \pm 0.026 \mu \mathrm{g} \mathrm{N}(0.18-$ $1.2 \mu \mathrm{g} \mathrm{N})$, and $\pm 0.25 \%$ o $(1 \sigma, n=8,1.4-9.6 \mu \mathrm{g} \mathrm{C})$, respectively. The TOC/TN ratio was calculated as the atomic ratio, and propagated errors ranged from \pm 0.29 to \pm 0.83 .

\section{Results}

\subsection{Sedimentary units determined by core description and ITRAX elemental variations}

Cores PL04 and PC04 are mainly composed of homogeneous gray mud layers intercalated with coarser layers of silty sand. The coarse-grained layers are olive-black in color and mostly $<2 \mathrm{~cm}$ thick. These coarse-grained layers have sharp basal contacts, and some have crosslaminations and faint parallel laminations. Most coarsegrained layers are recognizable by their coarser grain size and upward-fining trend. Most of their basal contacts are easily identifiable by a change in grain size, whereas some of their upper contacts are indistinct. No foraminifera or fragments thereof were identified in either core. Based on deep-sea turbidite classification criteria (e.g., Shanmugam 2000; Patton et al. 2015) and deep-water sediment facies (Stow and Shanmugam 1980; Stow and Smillie 2020), the silty sand beds are interpreted as turbidites and the mud layers as hemipelagites.

We were unable to obtain ITRAX profiles at $0.0-27.9$ $\mathrm{cm}, 83.1-91.3 \mathrm{~cm}$, and $163.9-169.1 \mathrm{~cm}$ depth in PC04 because of the soupy sediments. Variations of the elemental intensities were carefully compared with depth in the cores (Fig. 3). Ca (Fig. 3) and Sr intensities (not shown) are positively correlated with turbidite occurrence, and $\mathrm{Zr}$ is weakly correlated with $\mathrm{Ca}$ and $\mathrm{Sr}$. Fe, $\mathrm{Rb}$ (Fig. 3), Ti, and $\mathrm{K}$ (not shown), on the other hand, are negatively correlated with turbidite occurrence. In hemipelagites, $\mathrm{Ca}, \mathrm{Fe}$, and $\mathrm{Rb}$ intensities show minor fluctuations, whereas $\mathrm{K}$ and $\mathrm{Ti}$ show greater fluctuations. Other elements such as $\mathrm{Si}$ and $\mathrm{Al}$ did not show any significant correlation with these intercalated layers. Previous studies on marine sediments have demonstrated that the $\mathrm{Ca} / \mathrm{Fe}$ ratio is a useful proxy for terrigenous components in sediments, and $\mathrm{Zr} / \mathrm{Rb}$ is often positively correlated with mean grain size (Croudace et al. 2006; Rothwell and Croudace 2015). Therefore, we selected $\mathrm{Ca}, \mathrm{Fe}, \mathrm{Zr}$, and $\mathrm{Rb}$ as target elements to determine the boundaries of sedimentary units and coarse-grained layers (Fig. 3). The sedimentary units in cores PL04 and PC04 were determined mainly based on visual lithological descriptions and $\mathrm{Ca}$ variations.

We distinguished four major sedimentary units. Sedimentary unit 1 , found only in PL04, extends from the top to $62.0 \mathrm{~cm}$ depth in the core and consists of subparallel beds of hemipelagites interbedded with thin turbidite layers (Fig. 3). Thin turbidite layers $(<1 \mathrm{~cm})$ laminate within the hemipelagites. The average $\mathrm{Ca} / \mathrm{Fe}$ and $\mathrm{Zr} / \mathrm{Rb}$ ratios in this unit are about 0.06 and 0.90 , respectively (Fig. 3).

Sedimentary unit 2 is characterized by mounded or contorted interbeds in radiographs at $62.0-76.5 \mathrm{~cm}$ depth in PL04 and $0.0-55.0 \mathrm{~cm}$ depth in PC04. This unit contains more silt layers interbedded with the hemipelagites than unit 1 , and the silt layers are in olive-gray color. The exact boundary at $55.0 \mathrm{~cm}$ depth in PC04 was determined based on the radiographs and ITRAX profiles (Fig. 3). Sedimentary structures include crosslaminations, faint parallel laminations, and several tubular burrows. One sand layer at $~ 8-11 \mathrm{~cm}$ depth in PC04 (no available XRF data) can be correlated with a MS peak at $\sim 8 \mathrm{~cm}$ depth in the core (turbidite T0 in Fig. 4). In this unit, $\mathrm{Ca} / \mathrm{Fe}$ varies from 0.02 to 0.10 and $\mathrm{Zr} / \mathrm{Rb}$ from 0.60 to 1.40 (Fig. 3).

Sedimentary unit 3 extends from 55.0 to $322.0 \mathrm{~cm}$ depth in PC04 and consists of laminated fine-grained sands intercalated with gray hemipelagites. Bioturbations are observed at $55-75 \mathrm{~cm}$ depth in the core. Thirty-six coarsegrained layers were determined as turbidites, hereafter T1-T36. Turbidite thicknesses range from $\sim 0.9$ to 4.2 $\mathrm{cm}$. All 36 turbidites are correlated with $\mathrm{Ca} / \mathrm{Fe}$ peaks. Of these, 21 are correlated with $\mathrm{Zr} / \mathrm{Rb}$ peaks. Baseline $\mathrm{Ca} / \mathrm{Fe}$ ratios in hemipelagites are $\sim 0.02$, and peak $\mathrm{Ca} / \mathrm{Fe}$ values range from 0.05 to 0.18 in turbidites. Baseline $\mathrm{Zr} / \mathrm{Rb}$ ratios in hemipelagites are $\sim 0.70$, and peak $\mathrm{Zr} / \mathrm{Rb}$ values range from 0.90-1.59 in turbidites (Fig. 3). Magnetic susceptibility in unit 3 is less consistent with turbidites than in units 1 and 2: 6 of 7 MS peaks can be correlated with certain turbidites in unit 3 (Fig. 4). Disturbance of the sediments by the coring of $\mathrm{PC} 04$ becomes more pronounced below $262 \mathrm{~cm}$ depth in the core (Fig. 4). 
Sedimentary unit 4 extends from 322.0 to $532.0 \mathrm{~cm}$ depth in core PC04 and contains exclusively gray mud. Sediments in this unit show marked vertical streaking in contrast to the horizontal layers observed throughout the rest of the section, indicating substantial disturbance during coring. Elemental profiles are consistently uniform, and $\mathrm{Ca} / \mathrm{Fe}$ and $\mathrm{Zr} / \mathrm{Rb}$ ratios average $\sim 0.02$ and $\sim$ 0.80 , respectively.

\subsection{Magnetic parameters}

Analytical results of magnetic parameters comprise (1) K3 and MS, (2) the hysteresis loop from VSM measurements (Hc, Hcr, Mr, and Ms), and (3) SQUID-VSM measurements (Fig. 4). The first two sets of magnetic measurements were performed throughout the cores PL04 and PC04. After the detailed contacts between turbidites and hemipelagites had been determined, 30 samples from separate layers of the two sediment types (10 turbidites and 20 hemipelagites) were analyzed by SQUID-VSM.

K3 directions are roughly the same in undisturbed sediments, and gradually change below $262 \mathrm{~cm}$ depth in PC04 (i.e., in sediments disturbed by coring). No obvious MS peaks are observed in PL04, and eight are observed in separate sections of PC04 (Fig. 4). Hysteresis loop results show subtle variations. In the Day plot (the ratio of $\mathrm{Mr} / \mathrm{Ms}$ plotted against the ratio of $\mathrm{Hcr} / \mathrm{Hc}$; Day et al. 1977; Dunlop 2002), the samples plot in the pseudosingle-domain (PSD) and multi-domain (MD) fields (Fig. $5 \mathrm{e}$ ), indicating the fine grain size and uniformity of the cores. Hc and Hcr decrease gradually from the top to the bottom of the cored sections, and there are no obvious variations of $\mathrm{Mr}$ and $\mathrm{Ms}$ with depth in the cores (Fig. 4).

In SQUID-VSM measurements, low-temperature magnetic transitions at $34 \mathrm{~K}$ indicate the presence of monoclinic pyrrhotite in our samples (Fig. 5a, b; Rochette 1987; Dekkers et al. 1989), and those at $119 \mathrm{~K}$ indicate the presence of magnetite or magnetic clay minerals (Fig. 5c, d; Abrahams and Calhoun 1953). Pyrrhotite + magnetite signatures (solid diamonds, Fig. 4) are ubiquitous from the top of PL04 to $9.2 \mathrm{~cm}$ depth in PC04 (i.e., unit 1 and upper unit 2). Below $9.2 \mathrm{~cm}$ depth in PC04, pyrrhotite + magnetite signatures occur only in turbidites T25, T27, and T33, at $209.5 \mathrm{~cm}, 234.0 \mathrm{~cm}$, and $261.0 \mathrm{~cm}$ depth in PC04, respectively (Fig. 4). These three turbidites are also correlated with MS peaks. Magnetite signatures (i.e., in the absence of a pyrrhotite signature) occur in hemipelagites and other turbidites (open diamonds, Fig. 4).

\subsection{Turbidite observation and grain size analyses}

To further understand the characteristics of turbidites with high MS and pyrrhotite signatures, ten specimens from Turbidite T25 (207.0-212.0 cm depth in PC04) were selected for grain size analyses based on the visual core description and $\mathrm{Ca} / \mathrm{Fe}$ and $\mathrm{Zr} / \mathrm{Rb}$ ratios. Dispersed sediment particles from these ten samples were counted under a microscope with a $\times 20$ objective lens (Fig. 6). The sample from $209.75 \mathrm{~cm}$ depth in the core, a representative example of a turbidite (Fig. 6a, b), shows fine sand-sized grains and translucent minerals. The sample from $207.25 \mathrm{~cm}$ depth is representative of hemipelagites (Fig. 6c, d), which are markedly finer. More than 200, 000 particles were detected and photographed from each sample. Particle sizes mostly range from 0.54 to $63.0 \mu \mathrm{m}$ in CE diameter. The volume percentages of sand, silt, and clay in these samples are reported in Table 1 alongside mean circularities and aspect ratios. The average circularity in this sample set is 0.704 , and the average aspect ratio is 0.653 . The volume percentage of sand (> $63 \mu \mathrm{m}$ ) only exceeds $\sim 50 \%$ in the samples from 209.25 and $209.75 \mathrm{~cm}$ depth in the core, which are identified as silty sand.

\subsection{Radiocarbon dating, $\delta^{13} \mathrm{C}, \mathrm{TOC}$, and TN}

We performed radiocarbon dating and organic geochemistry analyses to compare turbidites and hemipelagites in core PC04, as identified based on the $\mathrm{Ca} / \mathrm{Fe}$ and $\mathrm{Zr} / \mathrm{Rb}$ proxies. The eight determined radiocarbon ages range from 17,680 to $26,710{ }^{14} \mathrm{C}$ yr $\mathrm{BP}$ in conventional age (Fig. 7, Table 2), including one turbidite (T0, $9.2 \mathrm{~cm}$ depth in PC04, 25,980 ${ }^{14} \mathrm{C}$ yr BP). The ages of the seven analyzed hemipelagites are not consistent with their stratigraphic depths; nonetheless, the youngest $(17,680$ ${ }^{14} \mathrm{C}$ yr BP, $195.0 \mathrm{~cm}$ depth in the core) is used to constrain the regional age model (Fig. 7). In PC04, we selected ten turbidites (T0, T4, T7, T9, T11, T20, T25, T27, T33, and T36; red triangles in Fig. 7) and eight hemipelagites (black circles in Fig. 7) for $\delta^{13} \mathrm{C}$, TOC, and TN analyses. These 18 samples show $\delta^{13} \mathrm{C}$ values from $-27.3 \%$ to $-21.8 \%$, TOC concentrations from 0.18 to 0.43 wt.\%, and TN concentrations from 0.037 to 0.088 wt.\%. TOC/TN ratios range from 4.64 to 6.75 .

\section{Discussion}

\subsection{Thin-bedded turbidites on the trench floor}

Grain size variations in fine-grained sediments can be predicted based on multi-elemental XRF analyses (Bertrand et al. 2015; Liu et al. 2019). However, these trends are difficult to observe in very thin-bedded turbidites $(1-3 \mathrm{~cm}$ thick). Because most of the 36 identified turbidites in PC04 are less than $2 \mathrm{~cm}$ thick, we selected turbidite T25 $(2.9 \mathrm{~cm}$ thick with a MS peak and magnetic pyrrhotite signatures) for grain size analysis (Fig. 8). Intensity variations of $\mathrm{Ca}, \mathrm{Fe}$, $\mathrm{Zr}$, and $\mathrm{Rb}$, and particularly $\mathrm{Ca} / \mathrm{Fe}$ and $\mathrm{Zr} / \mathrm{Rb}$, effectively trace sedimentary facies changes in PC04. Ca 

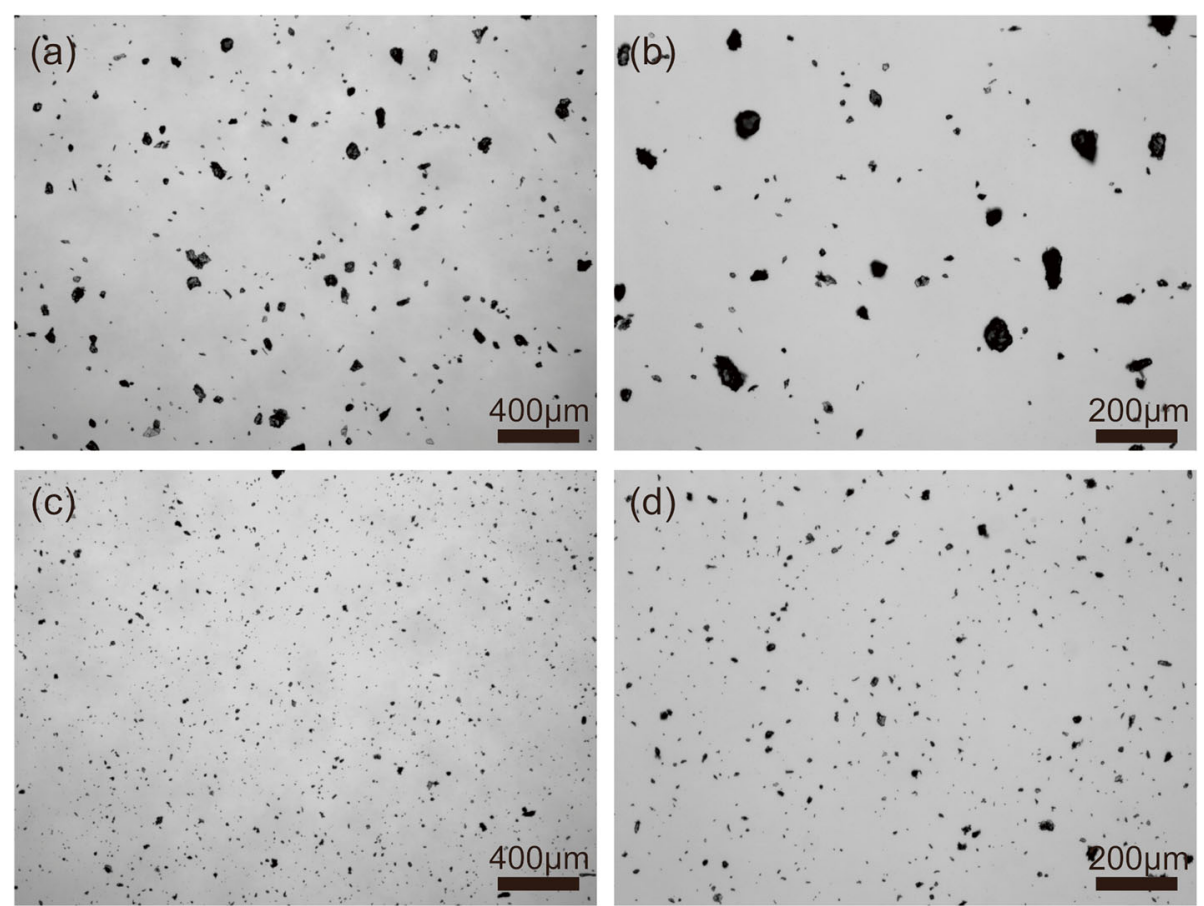

Fig. 6 Characteristic particles in samples from a, b $209.75 \mathrm{~cm}$ depth (turbidite T25, silty sand) and c, d $207.25 \mathrm{~cm}$ depth in PC04 (silt) observed using Morphologi-G3. Mean grain sizes and sand percentages of each $0.5 \mathrm{~cm}$-thick sample are shown in Fig. 8c and Table 1

variations mainly indicate $\mathrm{Ca}$ content, and negative Fe peaks may indicate increased water content (Fig. 3). The decreased $\mathrm{Fe}$, a common phenomenon in upper XRF-scan profiles or organic-rich sediments, is likely due to the closed-sum effect of increased $\mathrm{Ca}$ (e.g., Löwemark et al. 2011).

Deep-sea sediments usually contain both terrigenous and biogenic components. The water depth at the study site $(6147 \mathrm{~m})$ is below the carbonate compensation depth, which may play an important role in determining the biogenic carbonate content of the sediments. Ca intensities show that the carbonate contents of turbidites are consistently higher than those of hemipelagites. Furthermore, $\mathrm{Ca}$ and $\mathrm{Sr}$ intensities co-vary in PC04. Because $\mathrm{Sr}$ is fixed along with $\mathrm{Ca}$ by calcifying organisms, it is used in marine environments as a marker of sediments of strictly biogenic origin (Zaragosi et al. 2006). Therefore, the co-variation of $\mathrm{Ca}$ and $\mathrm{Sr}$ implies that $\mathrm{Ca}$ is mainly sourced from biogenic carbonates, with a minor contribution from terrigenous sources. The lack of biogenic material (e.g., foraminifera or fragments thereof) in both cores indicates that the seafloor in the southwestern Ryukyu Trench is below the carbonate compensation depth.

Compared to other elements, $\mathrm{Ca}$ and $\mathrm{Fe}$ variations show relatively small fluctuations in hemipelagites. $\mathrm{Ca}$ and $\mathrm{Fe}$ intensities are negatively correlated, and $\mathrm{Ca} / \mathrm{Fe}$

Table 1 Grain size analysis of turbidite T25 in core PCO4

\begin{tabular}{llllllll}
\hline Core depth $(\mathbf{c m})$ & Diameter $(\boldsymbol{\mu m})$ & Mean circularity & Mean aspect ratio & Sand $(\%)$ & Silt (\%) & Clay (\%) & Category \\
\hline 207.25 & 11.68 & 0.708 & 0.649 & 15.28 & 84.69 & 0.03 & Silt \\
207.75 & 9.57 & 0.739 & 0.656 & 9.16 & 90.77 & 0.07 & Silt \\
208.25 & 11.51 & 0.701 & 0.653 & 13.32 & 86.65 & 0.03 & Silt \\
208.75 & 16.76 & 0.693 & 0.666 & 29.51 & 70.48 & 0.01 & Sandy silt \\
209.25 & 31.72 & 0.670 & 0.636 & 65.57 & 34.42 & 0.00 & Silty sand \\
209.75 & 29.12 & 0.699 & 0.641 & 59.02 & 40.98 & 0.00 & Silty sand \\
210.25 & 14.83 & 0.679 & 0.637 & 46.60 & 53.39 & 0.01 & Sandy silt \\
210.75 & 12.72 & 0.738 & 0.668 & 33.54 & 66.43 & 0.02 & Sandy silt \\
211.25 & 12.48 & 0.704 & 0.668 & 21.01 & 78.97 & 0.02 & Silt \\
211.75 & 15.06 & 0.710 & 0.656 & 20.15 & 79.84 & 0.01 & Silt \\
\hline
\end{tabular}




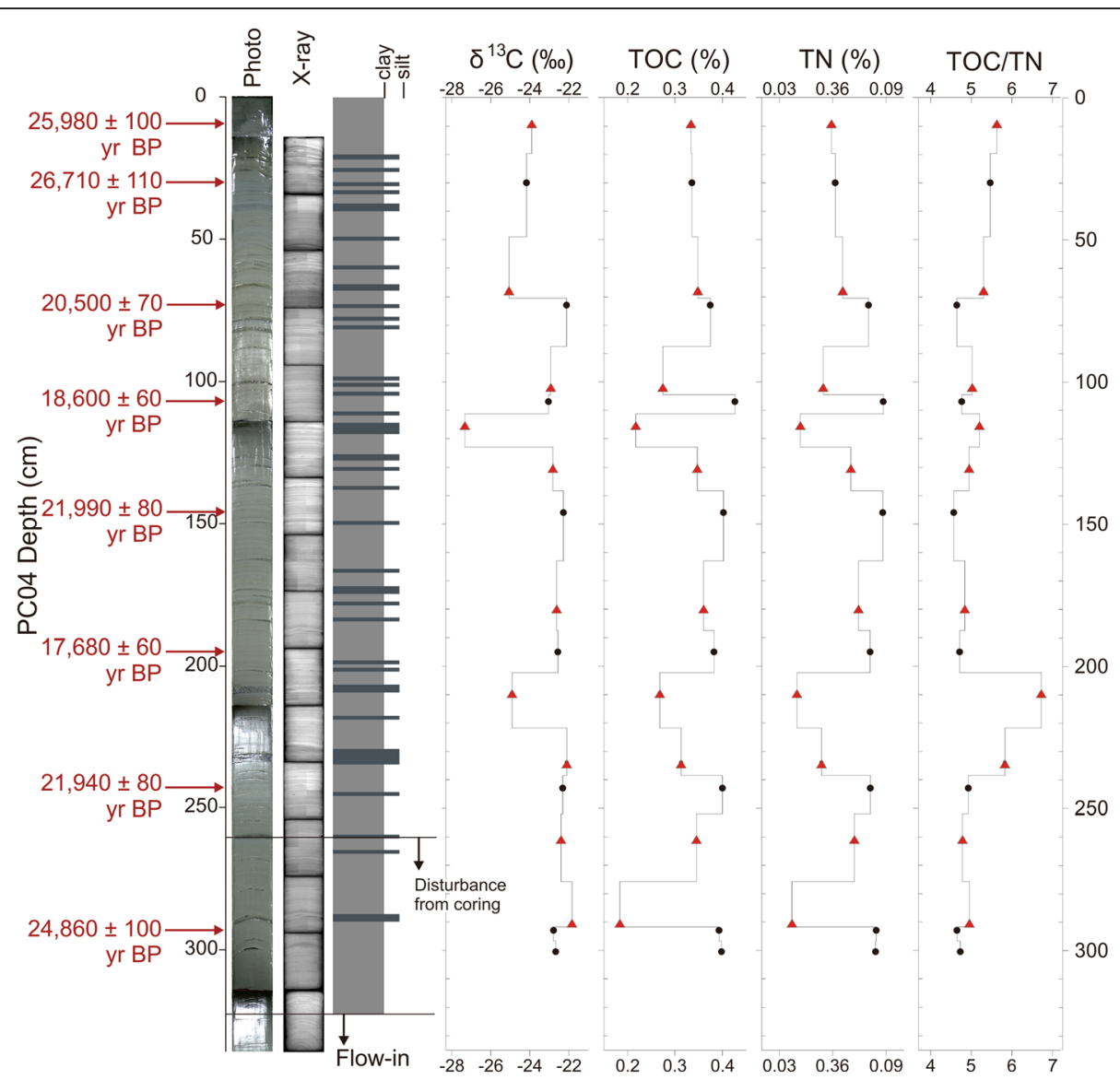

Fig. 7 Geochemical results from core $\mathrm{PC} 04$, including radiocarbon ages, stable carbon isotopic compositions $\left(\delta^{13} \mathrm{C}\right)$, total organic carbon contents (TOC), and total nitrogen contents (TN). Eight radiocarbon ages were determined from bulk sediments at locations marked by red arrows to the left of the section. Ten samples from turbidite beds (red triangles) and eight from hemipelagic sediments (black circles) in specific layers were selected for $\delta^{13} \mathrm{C}$, TOC, and TN analyses

peaks mark very thin-bedded turbidites in sedimentary unit 3 (Fig. 3). Except for eight peaks, MS variations are small in both cores (Fig. 4), indicating a purely depositional environment without hydrothermal or geothermal effects. Six MS peaks occur at the depths of turbidite layers showing extremely low Fe intensities (Fig. 4), which can be explained by the closed-sum effect with the Ca intensity.

$\mathrm{Zr}$ mainly occurs in zircon, which is usually enriched in coarse sediment fractions and indicates the presence of detrital grains. Considering $\mathrm{Zr}$ intensities alone, the peaks correlated with turbidites are not very sharp. However, $\mathrm{Zr} / \mathrm{Rb}$ provides a useful grain size proxy (Dypvik and Harris 2001) because $\mathrm{Zr}$ is present mainly in coarser grains and $\mathrm{Rb}$ in clays. Negative Rb peaks are sharp and clear (Fig. 3), indicating decreased clay percentages in the turbidites (Rothwell and Croudace 2015). Therefore, the observed $\mathrm{Zr} / \mathrm{Rb}$ peaks indicate increased abundances of coarse grains, and not necessarily terrigenous sediments. Although $\mathrm{Ca} / \mathrm{Fe}$ peaks are strongly correlated with $\mathrm{Zr} / \mathrm{Rb}$ peaks (correlation coefficient $r=0.80$ ) in PC04, 15 of the very thin-bedded turbidites $(<2 \mathrm{~cm}$ thick, $\mathrm{Ca} / \mathrm{Fe}<0.1)$ show only $\mathrm{Ca} / \mathrm{Fe}$ peaks; the grain size variations in these turbidites may be so subtle that $\mathrm{Zr} / \mathrm{Rb}$ variations are inconspicuous. This indicates that co-occurring peaks of $\mathrm{Ca} / \mathrm{Fe}$ and $\mathrm{Zr} / \mathrm{Rb}$ reflect coarser grained turbidites, whereas $\mathrm{Zr} / \mathrm{Rb}$ peaks are not observed in muddier turbidites.

Sedimentary units 1-3 show slight differences in the $\mathrm{Zr} / \mathrm{Rb}$ vs. $\mathrm{Ca} / \mathrm{Fe}$ plot (Fig. 9a, b). Elemental ratios of unit 2 show wider distributions than those of unit 1 (Fig. 9a). Sedimentary unit 3 is separated into turbidite beds (red triangles) and hemipelagites (gray dots; Fig. 9b), demonstrating the homogeneity of elemental ratios in unit 3 hemipelagites. The identification of turbidite peaks based on $\mathrm{Ca} / \mathrm{Fe}$ and $\mathrm{Zr} / \mathrm{Rb}$ in units 1 and 2 is difficult because of the strong variations in Ca content (Fig. 3); therefore, turbidites in these upper sections were mainly determined based on visual core descriptions and radiographs. The basal contact of each turbidite in unit 3 is easily identified as a change to coarser grain size based on $\mathrm{Ca} / \mathrm{Fe}$ and $\mathrm{Zr} / \mathrm{Rb}$. When plotted with symbol size 
Table 2 Radiocarbon ages from core PC04 compared to previous age results from the Ryukyu Arc

\begin{tabular}{|c|c|c|c|c|c|}
\hline Core & Depth (cm) & Conventional radiocarbon age & Water depth (m) & Material/sediment type & Reference \\
\hline \multirow[t]{8}{*}{ KR1518-PC04 } & $7.0-11.5$ & $25980 \pm 100$ & \multirow[t]{8}{*}{6147} & Bulk/turbidite & \multirow[t]{8}{*}{ This study } \\
\hline & $29.0-31.0$ & $26710 \pm 110$ & & Bulk/hemipelagite & \\
\hline & $72.0-74.0$ & $20500 \pm 70$ & & Bulk/hemipelagite & \\
\hline & 106.0-108.0 & $18600 \pm 60$ & & Bulk/hemipelagite & \\
\hline & $145.0-147.0$ & $21990 \pm 80$ & & Bulk/hemipelagite & \\
\hline & 194.0-196.0 & $17680 \pm 60$ & & Bulk/hemipelagite & \\
\hline & $242.0-244.0$ & $21940 \pm 80$ & & Bulk/hemipelagite & \\
\hline & $292.0-294.0$ & $24860 \pm 100$ & & Bulk/hemipelagite & \\
\hline \multirow[t]{2}{*}{$\mathrm{RN} 93-\mathrm{PC} 11^{\mathrm{a}}$} & $16.0-18.0$ & $1410 \pm 70$ & \multirow[t]{2}{*}{2540} & Foraminifera & \multirow[t]{2}{*}{ Ujiié and Ujiié (1999) } \\
\hline & $156.0-158.0$ & $13280 \pm 110$ & & Foraminifera & \\
\hline \multirow[t]{2}{*}{$\mathrm{RN} 93-\mathrm{PC} 12^{\mathrm{a}}$} & $28.0-30.0$ & $3360 \pm 80$ & \multirow[t]{2}{*}{2160} & Foraminifera & \multirow[t]{2}{*}{ Ujiié and Ujiié (1999) } \\
\hline & $136.0-138.0$ & $13420 \pm 110$ & & Foraminifera & \\
\hline \multirow[t]{11}{*}{ GH08-2004 } & $19.3-21.4$ & $3530 \pm 40$ & \multirow[t]{11}{*}{1166} & Foraminifera & \multirow[t]{11}{*}{ Kubota et al. (2015) } \\
\hline & $23.6-25.7$ & $4540 \pm 170$ & & Foraminifera & \\
\hline & $40.5-42.7$ & $6450 \pm 40$ & & Foraminifera & \\
\hline & 43.0 & 7300 & & Ash & \\
\hline & $67.3-69.5$ & $8265 \pm 100$ & & Foraminifera & \\
\hline & $80.7-82.9$ & $9320 \pm 40$ & & Foraminifera & \\
\hline & $127.6-129.8$ & $11660 \pm 50$ & & Foraminifera & \\
\hline & $134.3-136.0$ & $12265 \pm 110$ & & Foraminifera & \\
\hline & $142.9-145.2$ & $12940 \pm 70$ & & Foraminifera & \\
\hline & $172.8-175.1$ & $14955 \pm 115$ & & Foraminifera & \\
\hline & $225.6-227.9$ & $18780 \pm 100$ & & Foraminifera & \\
\hline
\end{tabular}

${ }^{\mathrm{a}}$ Ryukyu Arc core

proportional to turbidite thickness $(0.9-4.2 \mathrm{~cm})$, most of the thicker turbidites $(>2 \mathrm{~cm})$ plot above the general turbidite regression line and have smaller $\mathrm{Zr} / \mathrm{Rb}$ peak values (Fig. 9c). Generally, thicker turbidites show larger $\mathrm{Ca} / \mathrm{Fe}$ and $\mathrm{Zr} / \mathrm{Rb}$ ratios. Turbidite $\mathrm{T} 25$
( $2.9 \mathrm{~cm}$ thick) has the highest $\mathrm{Ca} / \mathrm{Fe}$ value (red circle, Fig. 9c), and turbidite T27 (the thickest observed, $4.2 \mathrm{~cm}$ thick; green circle, Fig. 9c) has one of the highest $\mathrm{Zr} / \mathrm{Rb}$ ratios. Both $\mathrm{T} 25$ and $\mathrm{T} 27$ show MS peaks and magnetic pyrrhotite signatures.

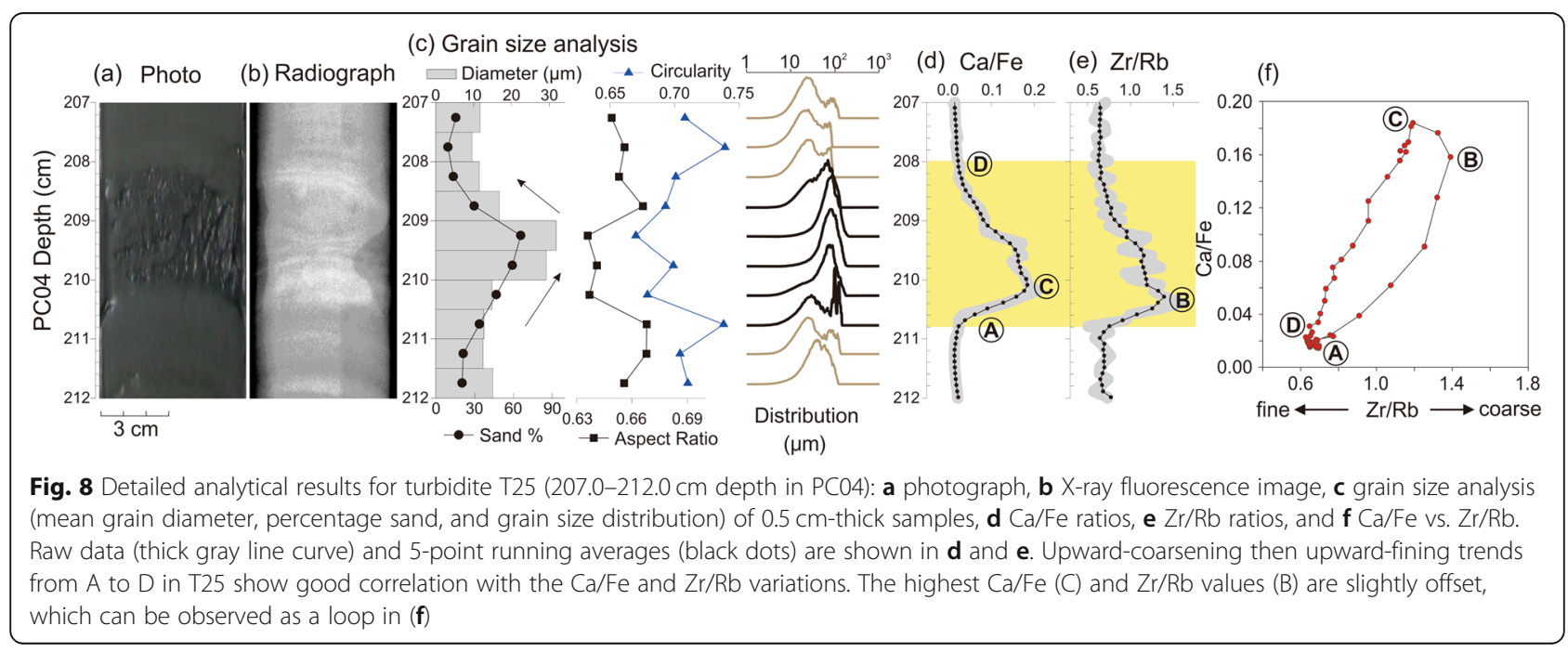



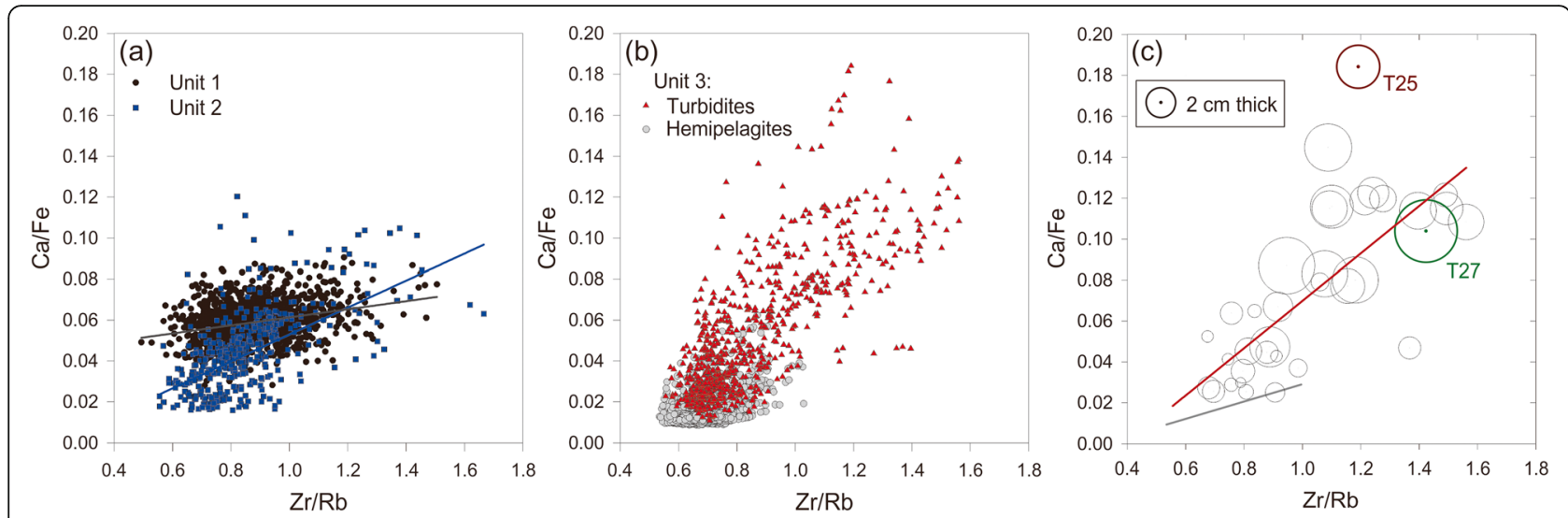

Fig. 9 Plots of $\mathrm{Ca} / \mathrm{Fe}$ vs. Zr/Rb for a sedimentary units 1 (black circles) and 2 (blue squares), b hemipelagites (gray circles) and turbidites of sedimentary unit 3 (red triangles), and c 36 individual turbidites (maximum values). Regressions for sedimentary units 1 and 2 are shown as black and blue lines, respectively, in $\mathbf{a}$. Symbol sizes in c represent the thickness of each turbidite bed. Turbidite T25 (red circle, $2.9 \mathrm{~cm}$ thick) has the highest Ca/Fe value of all analyzed turbidite beds. Turbidite T27 (green circle) is the thickest observed turbidite bed (4.2 cm). Regressions for turbidites and hemipelagites are shown as red and gray lines, respectively, in c

Our interpretation of $\mathrm{Ca} / \mathrm{Fe}$ ratios differs from that for shallow marine sediments. For example, the $\mathrm{Ca} / \mathrm{Fe}$ ratio is usually enhanced in coarse-grained, carbonateenriched materials (Fralick and Kronberg 1997; Marsh et al. 2007). Lehu et al. (2015) reported that Ca concentrations are higher in some turbidite layers and lower in others. Therefore, because shallow marine sediments may comprise both biological and non-biological $\mathrm{Ca}$ bearing materials, $\mathrm{Ca} / \mathrm{Fe}$ may not be applicable as an indicator of turbidites in shallow marine environments.

$\mathrm{Ca} / \mathrm{Fe}$ is useful as an indicator of turbidites in PC04 because the Ca-bearing components of the sediments mainly comprise biological materials. Even the lack of foraminifera or fragments, the co-variation of $\mathrm{Ca}$ and $\mathrm{Sr}$ intensities imply that biogenic source is dominated in PC04 rather than terrigenous. TOC contents are relatively low in both turbidites and hemipelagites of PC04 (Fig. 10) compared to those of shallow marine sediments. The PC04 turbidite is characterized by relatively low TOC content, high TC content, and high $\mathrm{Ca}$ intensity. It can be expected that the turbidites enriched in terrigenous components tend to dilute the TOC content. Therefore, $\mathrm{Ca} / \mathrm{Fe}$ should only be applied as an indicator of turbidites under consideration of the carbonate sources.

\subsection{The presence of pyrrhotite in turbidites}

Seven of the identified turbidites (T0, T5, T7, T9, T25, T27, and T33) coincide with MS peaks (Fig. 4), three of which (T25, T27, and T33) also coincide with magnetic pyrrhotite signatures. Because they are interbedded with pyrrhotite-absent turbidites, these three pyrrhotite-

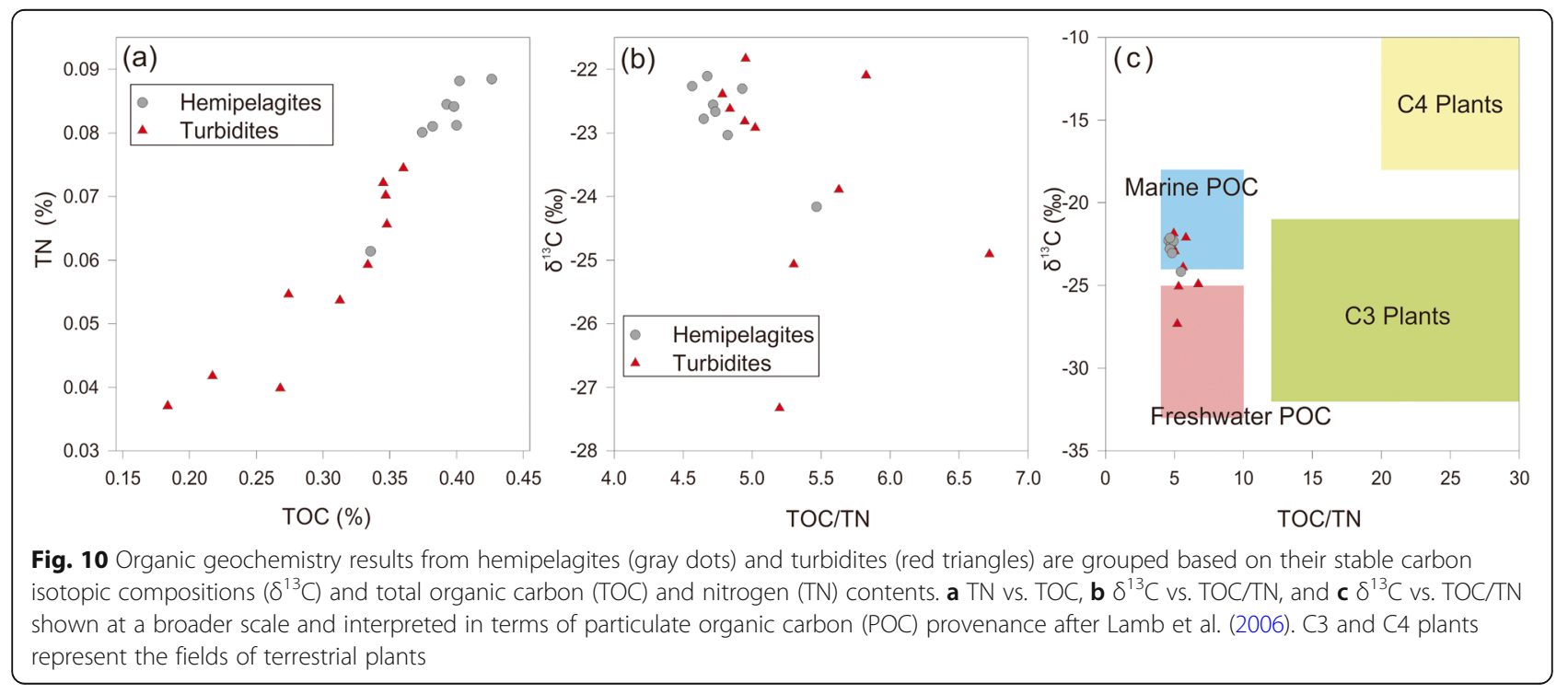


bearing turbidites must have been generated by three individual long-runout turbidity currents and likely transported sediments from Taiwan to the Ryukyu Trench floor via submarine canyons (Horng et al. 2012; see next subsection). These pyrrhotite-bearing (thus Taiwansourced) turbidites represent a small fraction of the sediments but not the percentage in these cores.

Regarding the sample preservation of T25, T27, and T33, we chose pyrrhotite-bearing turbidite T25 as a representative sample for detailed grain size analyses (Fig. 8). The mean grain diameter and sand percentage curves show maxima at $209.25-209.75 \mathrm{~cm}$ depth in the core, and the circularity, aspect ratio, and grain size distribution define a well-sorted layer at $209.25-210.25 \mathrm{~cm}$ depth (Fig. $8 \mathrm{c}$, Table 1). The grain size trend of T25 also coincides with peaks in the $\mathrm{Ca} / \mathrm{Fe}$ and $\mathrm{Zr} / \mathrm{Rb}$ profiles: the highest $\mathrm{Ca} / \mathrm{Fe}$ and $\mathrm{Zr} / \mathrm{Rb}$ values within T25 are labeled $\mathrm{C}$ and $\mathrm{B}$, respectively, in Fig. 8. The plot of $\mathrm{Ca} / \mathrm{Fe}$ vs. $\mathrm{Zr} / \mathrm{Rb}$ shows the upward-fining section as a tilted loop from $\mathrm{A}$ to $\mathrm{D}$ (Fig. 8f), implying the gradational nature of the bed and the asymmetry of the $\mathrm{Ca} / \mathrm{Fe}$ and $\mathrm{Zr} / \mathrm{Rb}$ peaks. We note that the peak grain size occurs above the peaks in elemental ratios ( $\mathrm{B}$ and $\mathrm{C}$ in Fig. $8 \mathrm{~d}$ and e), which might be due to the sampling interval: grain size analyses were performed at $0.5 \mathrm{~cm}$ intervals, a much coarser resolution than the ITRAX profile $(0.10 \mathrm{~cm}$ intervals). Nonetheless, the grain size distribution, circularities, and aspect ratios show an abrupt change from 210.75 to $210.25 \mathrm{~cm}$ depth, and this abrupt change at $\sim 211.0 \mathrm{~cm}$ depth is better correlated to the peaks in elemental ratios (Fig. 8c-e). In fine-grained sediments, homogeneous particles in well-sorted turbidites might slightly enhance ITRAX peaks. Therefore, the ITRAX peaks in this depth interval are mainly correlated with grain size, and ITRAX peaks may generally be enhanced in well-sorted turbidites.

Figure $8 f$ elaborates the upward-coarsening then upwardfining trend of turbidite T25, as well as the offset between the maximum grain size and elemental ratios. Indeed, the slight $0.2 \mathrm{~cm}$ offset of the $\mathrm{Ca} / \mathrm{Fe}$ and $\mathrm{Zr} / \mathrm{Rb}$ peaks manifests as a counterclockwise loop in the $\mathrm{Ca} / \mathrm{Fe}$ vs. $\mathrm{Zr} / \mathrm{Rb}$ plot. Similar slight offsets are observed in the ITRAX records of other turbidites thicker than $2 \mathrm{~cm}$ in PC04. This phenomenon should be further explored at adjacent sites.

In summary, our analyses of turbidite T25 demonstrate that $\mathrm{Zr} / \mathrm{Rb}$ peaks indicate increased abundances of coarse particles. High-resolution ITRAX data are useful for identifying very thin-bedded turbidites and sedimentary facies, especially in fine-grained trench sediments (e.g., Pérez et al. 2019).

\subsection{Source-to-sink: from the Taiwan orogenic belt to the oceanic trench}

Previous investigations have shown that the magnetic carriers in central Ryukyu Trench sediments are predominantly magnetite and maghemitized magnetite with minor amounts of hematite (Kawamura et al. 2008), which is not the case in southwestern Ryukyu Trench floor sediments (Hsiung et al. 2017). In this region, the presence of pyrrhotite with a magnetic signature strongly indicates that some portion of the sediments was sourced from metamorphic rocks of the Taiwan orogenic belt (Horng et al. 2012). Pyrrhotitebearing turbidites T25, T27, and T33 can thus be regarded as direct evidence that long-runout turbidity currents can feasibly transport Taiwan orogenic sediments to the Ryukyu Trench floor. In a holistic view, intense erosion of the uplifted Taiwan orogen due to the ongoing arc-continent collision between the Luzon Arc and the Asian continent produces a large amount of sediments that are transported seaward (Dadson et al. 2005). Indeed, sediments derived from the Taiwan orogenic belt are transported to the slope off eastern Taiwan and the Huatung Basin through major submarine canyons such as the Hualien, Chimei, and Taitung Canyons (e.g., Lehu et al. 2015). Furthermore, the canyon network connecting the Hualien Basin to the Ryukyu Trench is an effective pathway delivering terrestrial sediments from Taiwan to the southwestern Ryukyu Trench (Hsiung et al. 2017).

The continuous magnetic pyrrhotite signatures observed in hemipelagites of PL04 and the uppermost part of PC04 (Fig. 4) may indicate the ongoing contribution of terrestrial sediments transported from Taiwan Island (Fig. 2b). Considering globally decelerating sea-level rise during the Holocene (Stanley and Warne 1994) and the mid-Holocene warm period roughly 6000 years ago, the continuous pyrrhotite signatures observed in the upper part of PC04 (Fig. 4) may speculatively be linked to Holocene climate change. Another interpretation is that the volume of orogenic sediments shed from Taiwan is large and easily distributed to the southwestern Ryukyu Trench. However, the simple presence or absence of pyrrhotite cannot be used to quantify sediment contributions, and the sampling distribution and small sample size $(\sim 0.2 \mathrm{~g})$ in this study may not be of sufficient resolution to capture the pyrrhotite signatures of thinner turbidites. Although this study area may also receive sediments from the Ryukyu island arc and forearc regions, the absence of thick turbidite sequences and ash layers in PL04/PC04 implies a distal sedimentary environment far from the Ryukyu Islands to the north, and thus a dominant terrestrial source (Taiwan) to the west.

\subsection{Age model and relict organic carbon}

We obtained non-chronological radiocarbon ages from the bulk core sediments, implying that those sediments contain some amounts of relict organic carbon. Based on the age of $25,980{ }^{14} \mathrm{C}$ yr BP obtained for turbidite T0 
(7-11.5 cm depth in PC04), such relatively old ages may be affected by relict organic carbon (Table 2). Such carbon recycling along the seafloor requires that turbidity currents entrain organic carbon from bedload sediments during transport. Based on the youngest age obtained in core PC04 $\left(17,680{ }^{14} \mathrm{C}\right.$ yr BP at $194.0-196.0 \mathrm{~cm}$ depth, Table 2), the sedimentation rate in the southwestern Ryukyu Trench can be roughly constrained to $\sim 1.1 \mathrm{~mm} /$ year. Radiocarbon ages measured from foraminifera in the nearby Ryukyu Arc indicate sedimentation rates of $\sim 1.2 \mathrm{~mm} /$ year (Kubota et al. 2015) and 1.0-1.2 mm/year (Ujiié and Ujiié 1999). The similarity of the sedimentation rates in the southwestern Ryukyu Trench and the Ryukyu Arc indicates that bulk radiocarbon ages are minimally disturbed by relict organic carbon. The water depth and lack of foraminifera in cores PL04 and PC04 indicate that the seafloor in the southwestern Ryukyu Trench is below the carbonate compensation depth.

Although the radiocarbon ages obtained for the trench sediments are varied, sedimentation rates are strongly affected by sediment source. For example, the sedimentation rate variability from $\sim 0.01$ to $\sim 2.96 \mathrm{~mm} /$ year (Ikehara et al. 2018) has been documented in the Japan Trench (>7500 $\mathrm{m}$ water depth). Because there are no major canyon systems along most parts of the Japan Trench, high primary (diatom) productivity in the Sanriku area provides the dominant influx of fresh biogenic particles there, determining the high sedimentation rates. Despite the relatively old age model for PC04, the high frequency of very thin-bedded turbidites interbedded with hemipelagites likely contributes to the observed deposition rate.

\subsection{Organic geochemistry of turbidites and hemipelagites on the Ryukyu Trench floor}

Organic geochemistry analyses $\left(\delta^{13} \mathrm{C}, \mathrm{TOC}\right.$, and TN) are useful for determining terrestrial sediment sources in deep-sea deposits, especially in this semi-isolated depositional environment (Lamb et al. 2006). For example, bulk organic $\delta^{13} \mathrm{C}$ values and TOC/TN ratios have been used to reveal sediments sources from estuarine environments (Yu et al. 2010). TOC/TN ratios are often used to differentiate marine from terrestrial organic matter because higher TOC/TN ratios reflect larger contributions of lignin phenols from terrestrial environments (Perdue and Koprivnjak 2007; Fernandes et al. 2011). As turbidites may contain sediments from both marine and terrestrial sources, we attempted to discriminate turbidites from hemipelagites based on organic geochemical analyses of bulk sediments from eight hemipelagites and ten turbidites (Fig. 7). The ten turbidite samples have TOC contents of $0.18-0.36 \%$, TN contents of $0.037-0.074 \%$, and $\delta^{13} \mathrm{C}$ values of -27.3 to $-21.8 \%$ (Figs. 7 and 10 ). Compared to these turbidites, the hemipelagites are characterized by higher average TOC $(0.39 \%)$ and TN contents $(0.081 \%)$ and slightly heavier average $\delta^{13} \mathrm{C}$ values $(-22.7 \%)$. Both the high TOC contents and low $\mathrm{TOC} / \mathrm{TN}$ ratios of the homogeneous hemipelagites in PC04 show a differentiation from the turbidites. Indeed, the low $\mathrm{Ca}$ intensities observed in the hemipelagites of PC04 (Fig. 4) indicate that most organic carbon resides in hemipelagites rather than turbidites. The turbidite containing a small amount of terrigenous component tend to dilute the TOC content. The TOC contents, TN contents, TOC/TN values, and $\delta^{13} \mathrm{C}$ values of Taiwanese rocks, sediments, and rivers are $\sim 0.42 \%, \sim 0.07 \%, 5.8-$ 6.5 , and about $-25 \%$, respectively (Kao and Liu 2000; Kao et al. 2014). Therefore, PC04 turbidites show a wider range of values than Taiwan-sourced sediments.

\section{Conclusions}

This study presented very thin-bedded turbidites intercalated with hemipelagites in cores PL04 and PC04, obtained at $6147 \mathrm{~m}$ water depth on the Ryukyu Trench floor. We subdivided these cores into four sedimentary units based on visual core descriptions and variations of $\mathrm{Ca}$ intensities in ITRAX scans. Two sediment types, hemipelagites and turbidites, were identified mainly based on ITRAX $\mathrm{Ca} / \mathrm{Fe}$ and $\mathrm{Zr} / \mathrm{Rb}$ ratios. The contacts of 36 turbidites $(0.9-4.2 \mathrm{~cm}$ thick) were determined based on $\mathrm{Ca} / \mathrm{Fe}$ peaks. Three of these turbidites also presented MS peaks and magnetic signatures of pyrrhotite, which we interpret as evidence of long-range sediment transport from Taiwan to the Ryukyu Trench floor by long-runout turbidity currents traveling through submarine canyons. Detailed grain size analyses of a relatively thick turbidite showed good correlation between elemental ratios $(\mathrm{Ca} / \mathrm{Fe}$ and $\mathrm{Zr} / \mathrm{Rb})$ and the upwardcoarsening and upward-fining units that delimit the bottom and top of turbidites, respectively. These results suggest that both $\mathrm{Ca} / \mathrm{Fe}$ and $\mathrm{Zr} / \mathrm{Rb}$ can be used to identify distal turbidites (about $1-3 \mathrm{~cm}$ thick), with $\mathrm{Zr} / \mathrm{Rb}$ ratios mainly reflecting grain size changes in deep-sea sediments below the carbonate compensation depth. Some very thin-bedded turbidites $(<2 \mathrm{~cm}$ thick, $\mathrm{Ca} / \mathrm{Fe}<0.1)$ were identified based on their $\mathrm{Ca} / \mathrm{Fe}$ value, but we did not observe coincident $\mathrm{Zr}$ / $\mathrm{Rb}$ peaks; grain size variations in such thin turbidites may be so subtle that $\mathrm{Zr} / \mathrm{Rb}$ variations are inconspicuous. We observed pyrrhotite magnetic signatures in hemipelagites from the top of PL04 to $9.2 \mathrm{~cm}$ depth in PC04, indicating that Taiwan-sourced sediments may have been consistently dispersed as far as the southwestern Ryukyu Trench over the last several thousand years. Sedimentary organic matter was characterized $\left(\delta^{13} \mathrm{C}\right.$, TOC, and TN) to further discriminate turbidites from hemipelagites. The results concluded that hemipelagites are characterized by low $\mathrm{Ca}$ intensities, high TOC and TN contents, and heavy $\delta^{13} \mathrm{C}$ values, whereas turbidites show high $\mathrm{Ca}$ intensities and peak $\mathrm{Ca} / \mathrm{Fe}$ values. 


\section{Abbreviations}

${ }^{14} \mathrm{C}$ yr BP: Radiocarbon years before the present; JAMSTEC: Japan Agency for Marine-Earth Science and Technology; RN: Research vessel; SQUIDVSM: Superconducting quantum interference vibrating sample magnetometer; XRF: X-ray fluorescence; TOC: Total organic carbon; TN: Total nitrogen

\section{Acknowledgements}

We thank the anonymous reviewers for their careful reading of our manuscript and their constructive comments. We gratefully recognize the efforts of Captain Takafumi Aoki, the crew of RN Kairei, and the marine technicians of Marine Work Japan Ltd. during the KR15-18 survey. The ITRAX measurements were performed as part of the cooperative research program of the Center for Advanced Marine Core Research, Kochi University, Japan (No. $16 \mathrm{~A} 036$ and 16B032)

\section{Authors' contributions}

$\mathrm{KHH}, \mathrm{TK}, \mathrm{Kl}$, and $\mathrm{KU}$ worked together during the cruises and collaborated to construct this manuscript. $\mathrm{KHH}$ proposed the topic and conceived and designed the study. CSH helped perform SQUID-VSM analyses. N Ohkouchi and $\mathrm{N}$ Ogawa helped analyze and interpret the $\delta^{13} \mathrm{C}$, TOC, and TN data. SS and MM assisted with ITRAX analyses. All authors read and approved the final manuscript.

\section{Funding}

Cruises YK15-01 and KR15-18 were supported by the research project for Compound Disaster Mitigation on the Great Earthquakes and Tsunamis Around the Nankai Trough Region of the Japanese Ministry of Education, Culture, Sports, Science, and Technology, Japan. This core analysis was supported by the Japan Agency for Marine-Earth Science and Technology, Japan.

\section{Availability of data and materials}

The datasets supporting the conclusions of this article are available in the JAMSTEC repository.

\section{Competing interests}

The authors declare that they have no competing interest.

\section{Author details}

${ }^{1}$ Yokosuka Headquarters, Japan Agency for Marine-Earth Science and Technology, 2-15, Natsushima-cho, Yokosuka-city, Kanagawa 237-0061, Japan. ${ }^{2}$ Geological Survey of Japan, National Institute of Advanced Industrial Science and Technology, Central 7, 1-1-1 Higashi, Tsukuba, Ibaraki 305-8567, Japan. ${ }^{3}$ Safety and Environment Analysis Unit, Energy Consulting Department, Japan NUS Co., Ltd., Nishi-Shinjuku Prime Square 5F, 7-5-25 Nishi-Shinjuku, Shinjuku-Ku, Tokyo 160-0023, Japan. ${ }^{4}$ Institute of Earth Sciences, Academia Sinica, 128 Academia Road, Section 2, Nankang, Taipei 11529, Taiwan. ${ }^{5}$ Faculty of Agriculture and Marine Science, Kochi University, 200 Monobe, Nankoku-shi, Kochi 783-8502, Japan.

Received: 17 February 2020 Accepted: 2 December 2020 Published online: 04 January 2021

\section{References}

Abrahams SC, Calhoun BA (1953) The low-temperature transition in magnetite. Acta Crystallographica 6(1):105-106

Angelier J (1986) Geodynamics of the Eurasia-Philippine Sea Plate Boundary: preface. Tectonophysics 125(1-3):IX-X

Becker LW, Hjelstuen BO, Støren EW, Sejrup HP (2018) Automated counting of sand-sized particles in marine records. Sedimentology 65(3):842-850

Bertrand S, Hughen K, Giosan L (2015) Limited influence of sediment grain size on elemental XRF core scanner measurements. In: Micro-XRF Studies of Sediment Cores. Springer, Dordrecht, pp 473-490

Blott SJ, Pye K (2012) Particle size scales and classification of sediment types based on particle size distributions: review and recommended procedures. Sedimentology 59(7):2071-2096

Covault JA, Fildani A, Romans BW, McHargue T (2011) The natural range of submarine canyon-and-channel longitudinal profiles. Geosphere 7:313-332
Croudace IW, Rindby A, Rothwell RG (2006) ITRAX: description and evaluation of a new multi-function X-ray core scanner. Geological Soc London Spec Publ 267(1):51-63

Dadson S, Hovius N, Pegg S, Dade WB, Horng MJ, Chen H (2005) Hyperpycnal river flows from an active mountain belt. J Geophysical Res Earth Surf 110(F4):F04016. https://doi.org/10.1029/2004JF000244

Davis D, Suppe J, Dahlen FA (1983) Mechanics of fold-and-thrust belts and accretionary wedges. J Geophysical Res 88:1153-1172

Day R, Fuller M, Schmidt VA (1977) Hysteresis properties of titanomagnetites: grainsize and compositional dependence. Physics Earth Planetary Inter 13(4):260-267

Dekkers MJ, Mattéi JL, Fillion G, Rochette P (1989) Grain-size dependence of the magnetic behavior of pyrrhotite during its low-temperature transition at 34 K. Geophysical Res Lett 16(8):855-858

Dominguez S, Lallemand S, Malavieille J, Schnürle P (1998) Oblique subduction of the Gagua ridge beneath the Ryukyu accretionary wedge system: insights from marine observations and sandbox experiments. Mar Geophysical Res 20(5):383-402

Dunlop DJ (2002) Theory and application of the Day plot (Mrs/Ms versus $\mathrm{Hcr} / \mathrm{Hc}$ ) 1. Theoretical curves and tests using titanomagnetite data. J Geophysical Res Solid Earth 107(B3):EPM 4-1-EPM 4-22. https://doi.org/10.1029/2001JB000486

Dypvik H, Harris NB (2001) Geochemical facies analysis of fine-grained siliciclastics using Th/U, Zr/Rb and (Zr+ Rb)/Sr ratios. Chem Geol 181(1):131-146

Fernandes L, Nayak GN, Ilangovan D, Borole DV (2011) Accumulation of sediment, organic matter and trace metals with space and time, in a creek along Mumbai coast, India. Estuarine Coastal Shelf Sci 91(3):388-399

Fralick PW, Kronberg BI (1997) Geochemical discrimination of clastic sedimentary rock sources. Sedimentary Geology 113(1-2):111-124

Horng CS, Huh CA, Chen KH, Lin CH, Shea KS, Hsiung KH (2012) Pyrrhotite as a tracer for denudation of the Taiwan orogen. Geochem Geophysics Geosystems 13(8):Q08Z47

Hsiung KH, Kanamatsu T, Ikehara K, Shiraishi K, Horng CS, Usami K (2017) Morpho-sedimentary features and sediment dispersal systems of the southwest end of Ryukyu Trench: A source-to-sink approach. Geo Mar Lett 37(6):561-577

Hsiung KH, Su CC, Yu HS, Chang JH (2015) Morphology, seismic characteristics and development of the sediment dispersal system along the Taiwan-Luzon convergent margin. Mar Geophysical Res 36(4):293-308

Ikehara K, Kanamatsu T, Nagahashi Y, Strasser M, Fink H, Usami K, Irino T, Wefer G (2016) Documenting large earthquakes similar to the 2011 Tohoku-oki earthquake from sediments deposited in the Japan Trench over the past 1500 years. Earth Planetary Sci Lett 445:48-56

Ikehara K, Usami K, Kanamatsu T (2020) Repeated occurrence of surface-sediment remobilization along the landward slope of the Japan Trench by great earthquakes. Earth Planets Space 72(1):1-9

Ikehara K, Usami K, Kanamatsu T, Arai K, Yamaguchi A, Fukuchi R (2018) Spatial variability in sediment lithology and sedimentary processes along the Japan Trench: use of deep-sea turbidite records to reconstruct past large earthquakes. Geological Soc London Spec Publ 456(1):75-89

JAMSTEC (2015) YOKOSUKA YK15-01 cruise data. JAMSTEC. https://doi.org/10. 17596/0001656 Accessed 2020-06-01

JAMSTEC (2016) KAIREI KR15-18 cruise data. JAMSTEC. https://doi.org/10.17596/ 0001234 Accessed 2020-06-01

Jarrard RD (1986) Relations among subduction parameters. Rev Geophysics 24: 217-284

Kao SJ, Hilton RG, Selvaraj K, Dai M, Zehetner F, Huang JC, Hsu SC, Sparkes R, Liu JT, Lee TY, Yang JYT, Galy A, Xu X, Hovius N (2014) Preservation of terrestrial organic carbon in marine sediments offshore Taiwan: mountain building and atmospheric carbon dioxide sequestration. Earth Surf Dyn 2(1):127-139

Kao SJ, Liu KK (2000) Stable carbon and nitrogen isotope systematics in a human-disturbed watershed (Lanyang-Hsi) in Taiwan and the estimation of biogenic particulate organic carbon and nitrogen fluxes. Glob Biogeochem Cycles 14(1):189-198

Kao SJ, Milliman JD (2008) Water and sediment discharge from smal mountainous rivers, Taiwan: the roles of lithology, episodic events, and human activities. J Geology 116(5):431-448

Karig DE (1973) Plate convergence between the Philippines and the Ryukyu Islands. Mar Geology 14(3):153-168

Kawamura N, Kawamura K, Ishikawa N (2008) Rock magnetic and geochemical analyses of surface sediment characteristics in deep ocean environments: a case study across the Ryukyu Trench. Earth Planets Space 60(3):179-189 
Kubota Y, Kimoto K, Itaki T, Yokoyama Y, Miyairi Y, Matsuzaki H (2015) Bottom water variability in the subtropical northwestern Pacific from $26 \mathrm{kyr}$ BP to present based on $\mathrm{Mg} / \mathrm{Ca}$ and stable carbon and oxygen isotopes of benthic foraminifera. Climate Past 11(6):803-824

Lallemand SE, Liu CS, Font Y (1997) A tear fault boundary between the Taiwan Orogen and the Ryukyu subduction zone. Tectonophysics 274(1-3):171-190

Lallemand SE, Theunissen T, Schnürle P, Lee CS, Liu CS, Font Y (2013) Indentation of the Philippine Sea plate by the Eurasia plate in Taiwan: details from recent marine seismological experiments. Tectonophysics 594:60-79

Lamb AL, Wilson GP, Leng MJ (2006) A review of coastal palaeoclimate and relative sea-level reconstructions using $\delta^{13} \mathrm{C}$ and $\mathrm{C} / \mathrm{N}$ ratios in organic material. Earth Sci Rev 75:29-57

Le Pichon X, liyama T, Chamley H, Charvet J, Faure M, Fujimoto H, Furuta T, Ida Y, Kagami H, Lallemant S, Leggett J, Murata A, Okada H, Rangin C, Renard V, Taira A, Tokuyama H (1987) The eastern and western ends of Nankai Trough: results of Box 5 and Box 7 Kaiko survey. Earth Planetary Sci Lett 83(1-4):199213

Lehu R, Lallemand S, Hsu SK, Babonneau N, Ratzov G, Lin AT, Dezileau L (2015) Deep-sea sedimentation offshore eastern Taiwan: facies and processes characterization. Mar Geology 369:1-18

Lin AT, Watts A, Hesselbo SP (2003) Cenozoic stratigraphy and subsidence history of the South China Sea margin in the Taiwan region. Basin Res 15(4):453-478

Liu D, Bertrand S, Weltje GJ (2019) An empirical method to predict sediment grain size from inorganic geochemical measurements. Geochem Geophysics Geosystems 20(7):3690-3704

Löwemark L, Bloemsma M, Croudace I, Daly JS, Edwards RJ, Francus P, Galloway JM, Gregory BRB, Huang JJS, JonesAF KM, Luo Y, Maclachlan S, Ohlendorf C, Patterson RT, Pearce C, Profe J, Reinhardt EG, Stranne C, Tjallingii R, Turner JN (2019) Practical guidelines and recent advances in the Itrax XRF corescanning procedure. Quaternary Int 514:16-29

Löwemark L, Chen HF, Yang TN, Kylander M, Yu EF, Hsu YW, Lee TQ, Song SR, Jarvis S (2011) Normalizing XRF-scanner data: a cautionary note on the interpretation of high-resolution records from organic-rich lakes. J Asian Earth Sci 40(6):1250-1256

Malatesta C, Gerya T, Crispini L, Federico L, Capponi G (2013) Oblique subduction modelling indicates along-trench tectonic transport of sediments. Nat Commun 4:2456

Malvern Instruments Ltd. (2017) Morphologi G3 user manual. https://www. malvernpanalytical.com/en/learn/knowledge-center/user-manuals/MAN041 OEN.

Marsh R, Mills RA, Green DR, Salter I, Taylor S (2007) Controls on sediment geochemistry in the Crozet region. Deep Sea Res Part II Top Stud Oceanography 54(18-20):2260-2274

Ogawa NO, Nagata T, Kitazato H, Ohkouchi N (2010) In: Ohkouchi N, Tayasu I, Koba K (eds) Ultra-sensitive elemental analyzer/isotope ratio mass spectrometer for stable nitrogen and carbon isotope analyses. Earth, Life, and Isotopes. Kyoto: Kyoto University Press, pp 339-353

Patton JR, Goldfinger C, Morey AE, Ikehara K, Romsos C, Stoner J, Djadjadihardja Y, Udrekh AS, Gaffar EZ, Vizcaino A (2015) A 6600 year earthquake history in the region of the 2004 Sumatra-Andaman subduction zone earthquake. Geosphere 11(6):2067-2129

Perdue EM, Koprivnjak JF (2007) Using the C/N ratio to estimate terrigenous inputs of organic matter to aquatic environments. Estuarine Coastal Shelf Sci 73(1-2):65-72

Pérez AL, Rey D, Martins V, Plaza-Morlote M, Rubio B (2019) Application of multivariate statistical analyses to ItraxTM core scanner data for the identification of deep-marine sedimentary facies: a case study in the Galician Continental Margin. Quaternary Int 514:152-160

Rochette P (1987) Metamorphic control of the magnetic mineralogy of black shales in the Swiss Alps: toward the use of "magnetic isogrades". Earth Planetary Sci Lett 84(4):446-456

Rothwell RG, Croudace IW (2015) Twenty years of XRF core scanning marine sediments: what do geochemical proxies tell us? In: Micro-XRF Studies of Sediment Cores. Springer, Dordrecht, pp 25-102

Schnürle P, Liu CS, Lallemand SE, Reed DL (1998) Structural insight into the south Ryukyu margin: effects of the subducting Gagua ridge. Tectonophysics 288(1):237-250

Shanmugam G (2000) 50 years of the turbidite paradigm (1950s-1990s): deepwater processes and facies models - a critical perspective. Mar Petroleum Geology 17(2):285-342
Sibuet JC, Hsu SK (2004) How was Taiwan created? Tectonophysics 379(1):159181

Sømme TO, Helland-Hansen W, Martinsen OJ, Thurmond JB (2009) Relationships between morphological and sedimentological parameters in source-to-sink systems: a basis for predicting semiquantitative characteristics in subsurface systems. Basin Res 21(4):361-387

Stanley DJ, Warne AG (1994) Worldwide initiation of Holocene marine deltas by deceleration of sea-level rise. Science 265:228-231

Stern RJ (2002) Subduction zones. Rev Geophysics 40:1012

Stow D, Smillie Z (2020) Distinguishing between deep-water sediment facies: turbidites, contourites and hemipelagites. Geosciences 10(2):68

Stow DA, Shanmugam G (1980) Sequence of structures in fine-grained turbidites: comparison of recent deep-sea and ancient flysch sediments. Sedimentary Geology 25(1-2):23-42

Tayasu I, Hirasawa R, Ogawa NO, Ohkouchi N, Yamada K (2011) New organic reference materials for carbon-and nitrogen-stable isotope ratio measurements provided by Center for Ecological Research, Kyoto University, and Institute of Biogeosciences, Japan Agency for Marine-Earth Science and Technology. Limnology 12(3):261-266

Thornburg TM, Kulm LD (1987) Sedimentation in the Chile Trench: depositional morphologies, lithofacies, and stratigraphy. Geological Soc Am Bull 98(1):3352

Ujiié H, Ujiié Y (1999) Late Quaternary course changes of the Kuroshio Current in the Ryukyu Arc region, northwestern Pacific Ocean. Mar Micropaleontol 37(1): $23-40$

Usami K, Ikehara K, Kanamatsu T, McHugh CM (2018) Supercycle in great earthquake recurrence along the Japan Trench over the last 4000 years. Geosci Lett 5(1):1-12

Van Avendonk HJA, Kuo-Chen H, Mclntosh KD, Lavier LL, Okaya DA, Wu FT, Wang CY, Lee CS, Liu CS (2014) Deep crustal structure of an arc-continent collision: constraints from seismic traveltimes in central Taiwan and the Philippine Sea. J Geophysical Res Solid Earth 119(11):8397-8416

Wu S, Takahashi N, Tokuyama H, Wong HK (2005) Geomorphology, sedimentary processes and development of the Zenisu deep-sea channel, northern Philippine Sea. Geo Mar Lett 25(4):230-240

Yu F, Zong Y, Lloyd JM, Huang G, Leng MJ, Kendrick C, Lamb AL, Yim WWS (2010) Bulk organic $\delta^{13} \mathrm{C}$ and $\mathrm{C} / \mathrm{N}$ as indicators for sediment sources in the Pearl River delta and estuary, southern China. Estuarine Coastal Shelf Sci 87(4):618-630

Zaragosi S, Bourillet JF, Eynaud F, Toucanne S, Denhard B, Van Toer A, Lanfumey $\checkmark$ (2006) The impact of the last European deglaciation on the deep-sea turbidite systems of the Celtic-Armorican margin (Bay of Biscay). Geo Mar Lett 26(6):317-329

\section{Publisher's Note}

Springer Nature remains neutral with regard to jurisdictional claims in published maps and institutional affiliations.

\section{Submit your manuscript to a SpringerOpen ${ }^{\circ}$ journal and benefit from:}

- Convenient online submission

- Rigorous peer review

- Open access: articles freely available online

- High visibility within the field

- Retaining the copyright to your article

Submit your next manuscript at $>$ springeropen.com 